$\mathrm{HW}-79143$

UC-25, Metals, Ceramics and Materials

(TID $-4500,23 r d$ Ed.)

\title{
ELECTRON BEAM WELDING
}

OF NUCLEAR FUEL CLADDING COM PONENTS

\section{By}

\section{R. F. Klein}

Ceramic Research and Development Operation

Reactor and Fuels Laboratory

Hanford Laboratories

FIRST UNRESTRICTED

DistRiBution made NOV $21 ' 63$

October 1963

\author{
HANFORD ATOMIC PRODUCTS OPERATION \\ RICHLAND, WASHINGTON
}

Work performed under Contract No. AT (45-1)-1350 between the Atomic Energy Commission and General Electric Company

Printed by/for the U. S. Atomic Energy Commission

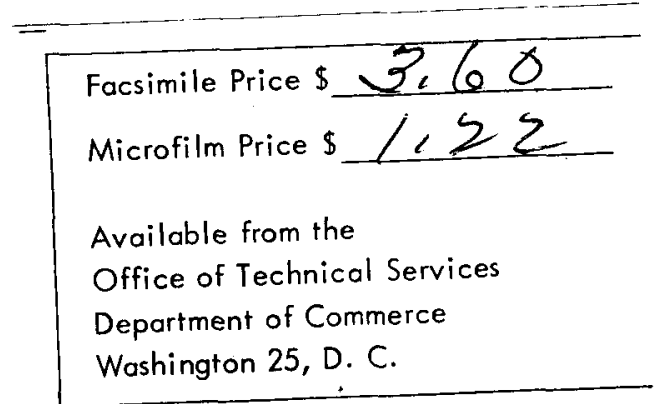




\section{DISCLAIMER}

This report was prepared as an account of work sponsored by an agency of the United States Government. Neither the United States Government nor any agency Thereof, nor any of their employees, makes any warranty, express or implied, or assumes any legal liability or responsibility for the accuracy, completeness, or usefulness of any information, apparatus, product, or process disclosed, or represents that its use would not infringe privately owned rights. Reference herein to any specific commercial product, process, or service by trade name, trademark, manufacturer, or otherwise does not necessarily constitute or imply its endorsement, recommendation, or favoring by the United States Government or any agency thereof. The views and opinions of authors expressed herein do not necessarily state or reflect those of the United States Government or any agency thereof. 


\section{DISCLAIMER}

Portions of this document may be illegible in electronic image products. Images are produced from the best available original document. 


\section{$\underline{\text { ABSTRACT }}$}

The rapid technological development of the nuclear and space industries has placed a great demand on metal joining processes. One of the most promising processes is electron beam welding. Welding with the electron beam offers high integrity in addition to the ability to fabricate unusual configurations. Advanced nuclear fuels require both reliability and unusual designs for satisfactory operation under extreme conditions of temperature and stress. To investigate the problems and techniques involved in fabricating large, advanced nuclear fuel components from Zircaloy-2 material, several cladding pieces were designed and built using the electron beam process. These designs included five basic joint types for assembling the cladding. Destructive and nondestructive examinations were employed including corrosion testing and extensive metallographic examination.

Weldment size, "fit-up" of the parts to be joined, fixturing and work carriage mechanisms, as they pertain to electron beam welding, are also discussed.

The electron beam process has been demonstrated as a very satisfactory method for fabricating unusual fuel cladding. Fuel cladding components with lengths up to $8 \mathrm{ft}$ have been fabricated for in-reactor irradiation. 
TABLE OF CONTENTS

$\underline{\text { Page }}$

INTRODUCTION . . . . . . . . . . . . . . . . . . . . . . . . . .

DISCUSSION . . . . . . . . . . . . . . . . . . 7

Size of Weldment. . . . . . . . . . . . . . . . . . . . . . . . 9

Fit-Up . . . . . . . . . . . . . . . . 10

Fixturing . . . . . . . . . . . . . . . . . . . . 12

Work Carriages . . . . . . . . . . . . . . . . . 12

WELDING RESULTS . . . . . . . . . . . . . . . . . . . . . . 13

Type 1 Weldments . . . . . . . . . . . . . . . . . . . 13

Type 2 Weldments . . . . . . . . . . . . . . . . . . . . . 15

Type 3 Weldments . . . . . . . . . . . . . . . . . . . . . 15

Type 4 Weldments . . . . . . . . . . . . . . . . . . . . . 20

Type 5 Weldments . . . . . . . . . . . . . . . . . . . . 20

Weld Joint Porosity. . . . . . . . . . . . . . . . . . . . . 26

Welding Parameters . . . . . . . . . . . . . . . . . 26

CONCLUSIONS. . . . . . . . . . . . . . . . . . . . . . . . . 29

ACKNOW LEDGMENT. . . . . . . . . . . . . . . . . . . . . . 29 


\section{LIST OF FIGURES}

Figure

Number

$\underline{\text { Page }}$

1 Weld Joint Descriptions and Designations . . . . . . . . 8

2 Tube-in-Tube Cross Section . . . . . . . . . . . . . . 10

3 Weld with Poor Fit-Up of Parts . . . . . . . . . . . . . 11

4 Weld with Good Part Fit-Up. . . . . . . . . . . . . . . 11

$5 \mathrm{~A}$

and Poor Fit-Up on Type 1 Weld. . . . . . . . . . . . . . . 14 $5 B$

6 Type 1 Weld with Electron Beam Penetration to One Side of Rib . . . . . . . . . . . . . . . . . . . 15

7 An Acceptable Type 1 Weld . . . . . . . . . . . . . . . 15

8 A Good Type 2 Weld . . . . . . . . . . . . . . . . 17

$9 \mathrm{~A}$

and

$9 \mathrm{~B}$

A Good Type 2 Weld . . . . . . . . . . . . . . 18

10 Incomplete Penetration on a Type 2 Weld . . . . . . . . . 19

11 Porosity in a Type $2 \mathrm{Weld}$. . . . . . . . . . . . . . . . 19

$12 \mathrm{~A}$

A Good Type 3 Weld . . . . . . . . . . . . . . 20

$13 \mathrm{~A}$

Excessive Penetration and Poor Fit on Type 3 Welds . . . 29

A Good Two-Pass Type 4 Weld . . . . . . . . . . 23

16 One-Pass Type 4 Weld Showing Insufficient Penetration . . 24

17 Two-Pass Type 4 Weld Showing Porosity . . . . . . . . . 24

18 One-Pass Type 4 Weld Showing Porosity . . . . . . . . . 25 


\section{LIST OF FIGURES (Cont'd)}

Figure

Number

20

21

22

23

24

25

26

27

Longitudinal Section of Type 1 and Type 2 Joints . . . . . 28

Enlargement of the Apparent Line Shown in the Lower Part of Figure 20 . . . . . . . . . . . . . . . . 28

Longitudinal Section of Type 3 Joint . . . . . . . . . . . 29 Longitudinal Section of Type 4 Joint . . . . . . . . . . . 29 Pre-Assembled 19-Rod Cluster and Tube-in-Tube Fuel Element Cladding Assemblies . . . . . . . . . . 31 Nested Tubular Cladding Parts . . . . . . . . . . . . 32 Arch-Supported Fuel Element Cladding . . . . . . . . . 33 Inverted Cluster Fuel Element Cladding . . . . . . . . . 34 


\section{ELECTRON BEAM WELDING}

\section{OF NUCLEAR FUEL CLADDING COMPONENTS}

\section{INTRODUCTION}

The continual development of nuclear and space-age metals and alloys has created a demand for improved welding technology. Some of the most promising heat and corrosion resistant materials are those that are the most difficult to refine, shape, and join. These materials include the reactive and refractory materials and their alloys--e.g., tungsten, molybdenum, tantalum, niobium, hafnium, titanium, beryllium, and zirconium. The relatively new process of electron beam welding has provided industry with the ability to fabricate these materials into a wide variety of structural components. The use of this process is not limited to hard-to-join materials. Electron beam welding provides a means of obtaining large depth-to-width ratios, high energy concentration in a small area, and extremely narrow heat affected zones. These advantages are not available in the more conventional processes.

While the idea of localized heating by bombardment of electrons is not new, the development of sophisticated equipment has occurred only within the last few years. This welding process derives its unique effect from a beam of electrons emitted from a cathode, usually made from tungsten. The beam is accelerated to a high velocity through a high potential and accurately focused by magnetic coils to produce a spot with an extremely high ene rgy density.

A vacuum chamber and suitable pumping equipment to provide a vacuum of approximately 1 torr are necessary for satisfactory operation of the electron beam. At a higher pressure, gas molecules would diffuse the electrons emitted from the cathode, so that a fine beam focus could not be obtained. 
Electron beam welding has been extended beyond the laboratory curiosity and experimental tool stage to a very successful production tool. Its major use, until recently, has been in the fabrication of relatively small parts. Today the use of the equipment is extending to larger and larger pieces as evidenced by the growing size of welding chambers.

\section{DISCUSSION}

The low cost fabrication of nuclear fuel elements that will operate with high heat generation rates and complete safety is the ultimate objective of fuel element manufacturers. To this end, several unique fuel element cladding configurations were fabricated by electron beam welding to demonstrate the flexibility of the process and the feasibility of welding large, unusual shapes that cannot be readily fabricated by other methods. Sections of each piece of cladding were thoroughly examined by destructive and nondestructive techniques to determine depth of penetration, extent of heat-affected zone, and the amount of porosity.

Five basic electron beam welding joint designs were incorporated in four different cladding configurations. These joint designs are summarized in Figure 1. Arrows indicate direction of the electron beam and point to the area of beam impingement.

(1) The preparation of the parts for welding and the evaluation of the welded components were performed at Hanford. The components were welded by an offsite contractor. 


$$
\text { -8- HW }-79143
$$

\begin{tabular}{l} 
Joint Type \\
Designation \\
\hline
\end{tabular}

1

2

3

4

5

\section{Type of Weld}

Burn-Through

Tangential
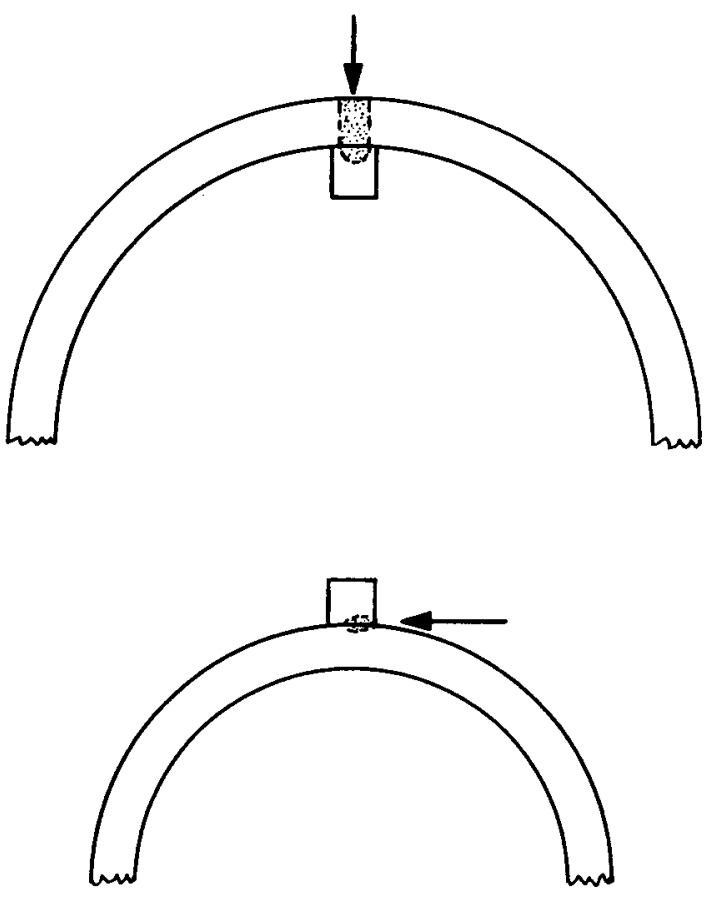

Burn-Through
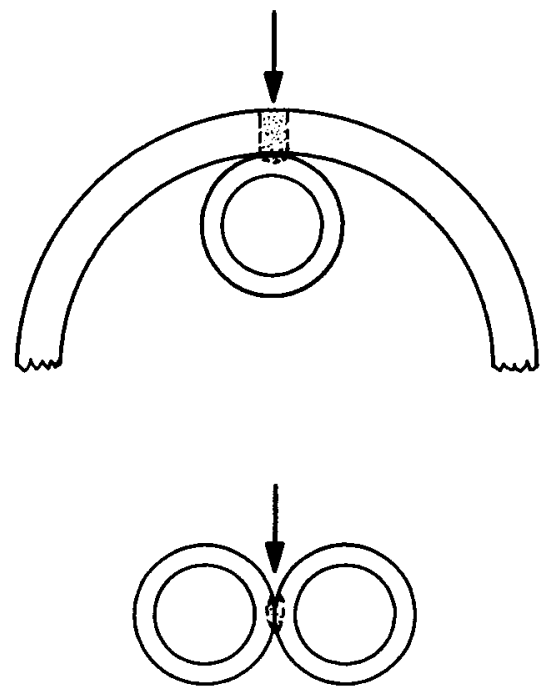

Tangential

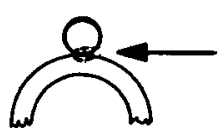

\section{FIGURE 1}

Weld Joint Descriptions and Designations 
Cladding dimensions are shown in Table I.

TABLE I

FUEL CLADDING DIMENSIONS

Joint

Type

Part

Dimensions

1

Tubular Cladding

$3.070 \mathrm{in.} O D \times 0.060$ in. wall

Rib

$0.062 \mathrm{in.}$ thick

2

Tubular Cladding

2. $330 \mathrm{in.}$ OD $\times 0.060$ in. wall

Rib

$0.062 \mathrm{in.} \mathrm{thick}$

3

Large Tubular Cladding

2. $330 \mathrm{in.} O D \times 0.060 \mathrm{in}$, wall

Small Tubular Cladding

0.565 in. $O D \times 0.30$ in. wall

4

Both Pieces of Tubular

Cladding

0.565 in. $O D \times 0.030$ in. wall

5

Tubular Cladding

0.565 in. OD $\times 0.030$ in. wall

Round Wire

0.072 in. diameter

Although electron beam welding offers the research worker and fabricator a method of making many unusual welds in addition to conventional joints, there are special considerations that must be taken into account. These considerations are not of serious importance when more conventional welding methods are employed.

Size of Weldment

Size and complexity of the equipment are increased when the physical size of the weldment is increased. A longitudinal weld on a $1 \mathrm{ft}$ long section is relatively easy to make, but an $8 \mathrm{ft}$ section can be considerably more difficult. When spacer ribs were welded to the outside of a $1 \mathrm{ft}$ long tube, distortion of the ribs was negligible. Little trouble from rib distortion or tube bow was encountered when this ribbed tube was inserted into a tube which had an ID the same dimension as the OD of the ribs, and "blind" burn-through welds were made through the outer tube into the ribs (Figure 2). Distortion of ribs (and tube), when welded to an $8 \mathrm{ft}$ long tube, would 
not be negligible without elaborate fixturing to restrain the rib and tube. The burn-through weld is considerably more difficult to make on the $8 \mathrm{ft}$ long section than on the $1 \mathrm{ft}$ long section because the distorted rib cannot be seen through the outer tube. Also, since tube bow varies with length, good fit-up and the burn-through weld would be difficult to achieve.

Cost of weldment, then, increases with length. Fixturing is necessarily more elaborate and more care is required to assure quality work. $\underline{\text { Fit-Up }}$

The fit-up of the pieces to be joined is important when conventional welding processes are used, but the importance is vastly increased with electron beam welding. This is due to the extremely small diameter beam impingement area. Welding longitudinal ribs to tubes is an example. There is essentially a point contact between the rib and the tube. If there is a gap between the rib and tube of as little as $0.015 \mathrm{in}$. at one point, no weld may occur at that point or, at best, a thinning of the weld metal near the tube will take place.

Another example of necessity of good fit-up is vividly illustrated in Figures 3 and 4 . The cross-section of this weldment is the same as Figure 2. Figure 3 shows the results of a gap between the rib and the

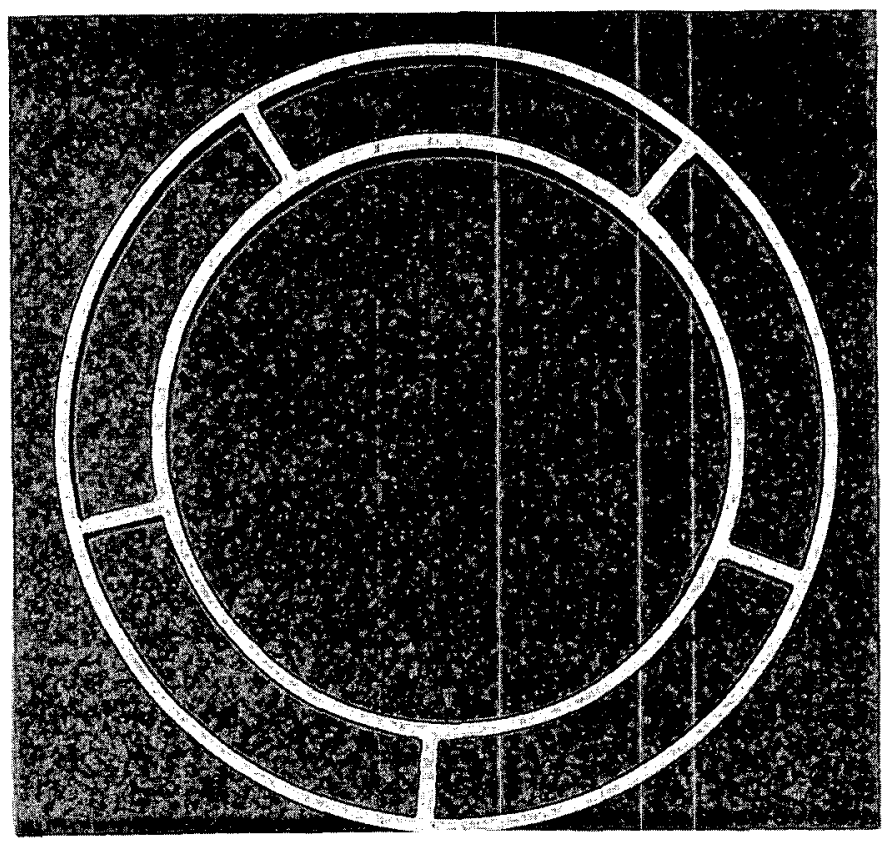

\section{FIGURE 2}

Tube-in-Tube Cross Section 


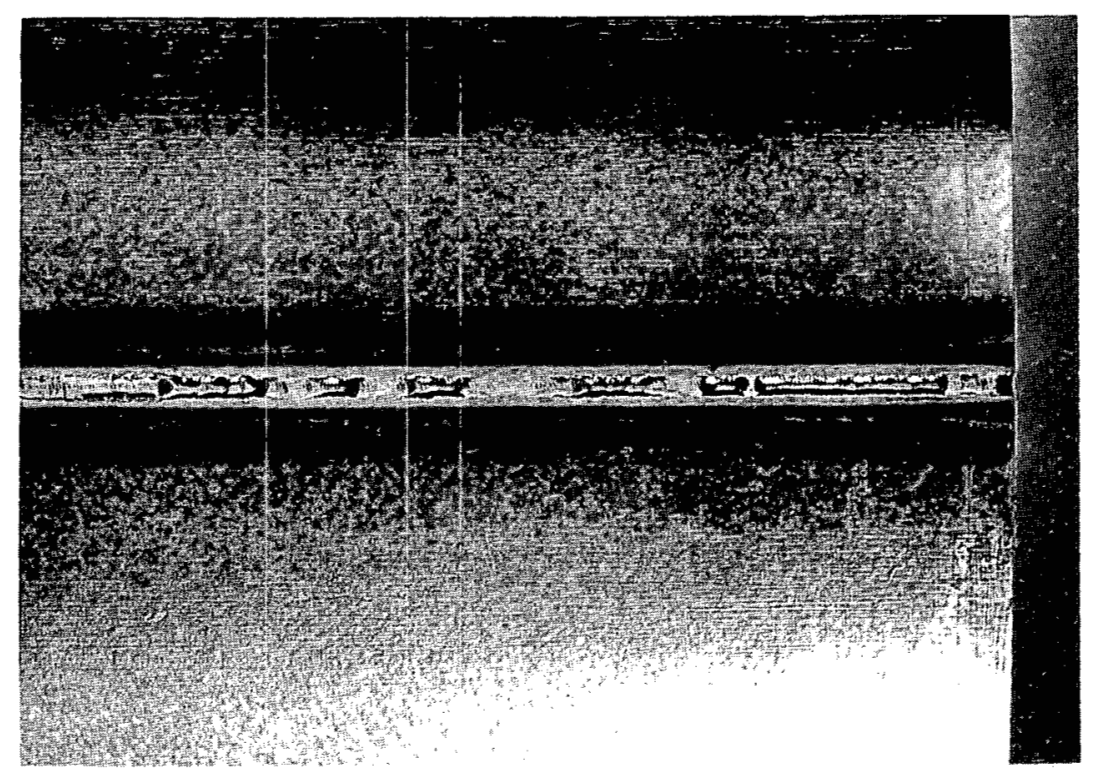

FIGURE 3

Weld with Poor Fit-up of Parts

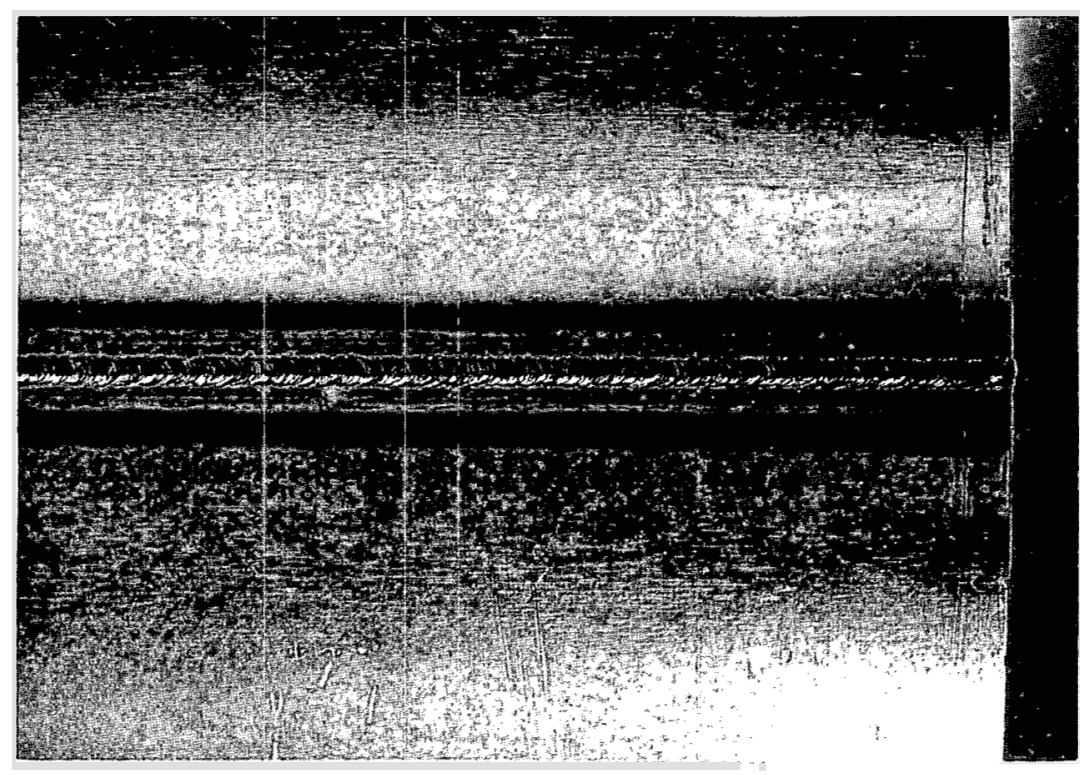

FIGURE 4

Weld with Good Part Fit-up 
inside of the outer tube. Figure 4 indicates the results obtained from a good fit-up of the same type of joint.

Fixturing

Fixturing plays an important part in obtaining quality welds on large, long or intricately shaped pieces. For research and development work, effective fixturing can be kept simple; however, production of a large number of long pieces may change the fixturing picture. Drive mechanisms may be introduced to rotate the part into a new position after each weld, automatic clamping devices may be required that can release parts and reclamp after positioning the pieces, storage and feeding mechanisms may be needed to supply parts, and all must be done in such a manner that the final product is a precise fabrication. Cost of elaborate fixturing may be high, and with each addition to the fixture an accompanying increase in the size of the vacuum chamber must be considered.

Work Carriages

Smooth operation and essentially vibration-free movement are necessary features of work carriages. Vibration control is one key to quality work. Where pinpoint accuracy in placement of the small diameter electron beam on the joint is necessary, any vibration which has a component horizontal to the direction of travel can be detrimental to the weld. Vibration in this direction will widen the weld unnecessarily and in some instances result. in burning through thin cladding. It will also greatly hamper the operator's control over the welding.

Accurate carriage travel is particularly important on long weldments. Carriage travel should not deviate more than 0.005 in. from a straight path. Furthermore, the importance of accurate carriage travel increases as the wall thickness of the tube decreases. Accurate carriage travel will require fewer operator adjustments and assure high quality welds. 


\section{WELDING RESULTS}

All welding was performed on reactor grade Zircaloy-2 material. Type $1 \mathrm{~W}$ eldments

Type 1 joints are burn-through welds in which the electron beam impinges radially on the surface of the outer tube. The beam completely penetrates the cladding and continues on into the rib material.

Figures $5 \mathrm{~A}$ and $5 \mathrm{~B}$ clearly show the result of a poor fit-up between rib and tube in this type of joint. The appearance of the outside of the tube when this condition exists is illustrated in Figure 3. Figure 5 shows that the area of the weld metal used to partially fill the void between the ID of the tube and the top of the rib is far greater than the area of the indentation at the top of the weld. The metal to fill the void must not have come from the tube material directly above the void. It must have come from the joint material on either side of the metal shown in the plane of this cross section. The porosity in this joint type will be discussed later along with porosity found in all of the four remaining joints.

The bulge of metal in Figure 6 is typical for this type of joint when the fit-up is good and the welding beam penetrates close to one side of the rib. There is essentially two-point contact between the rib and the tube, i.e., since the tube is curved, only the two edges of the rib will touch it. As the beam penetrates the tube, the rib edge close to the beam heats, melts, and the molten edge sags to form the bulge.

A good weld is illustrated in Figure 7 . There is good fit-up and the weld is only slightly off-center.

A Type 1 weld is considered perfect if the welding beam penetrates the exact center of the rib and the weld is wide enough to eliminate the slight crevices between the rib and the tube on either side of the weld metal as in Figure 7. 


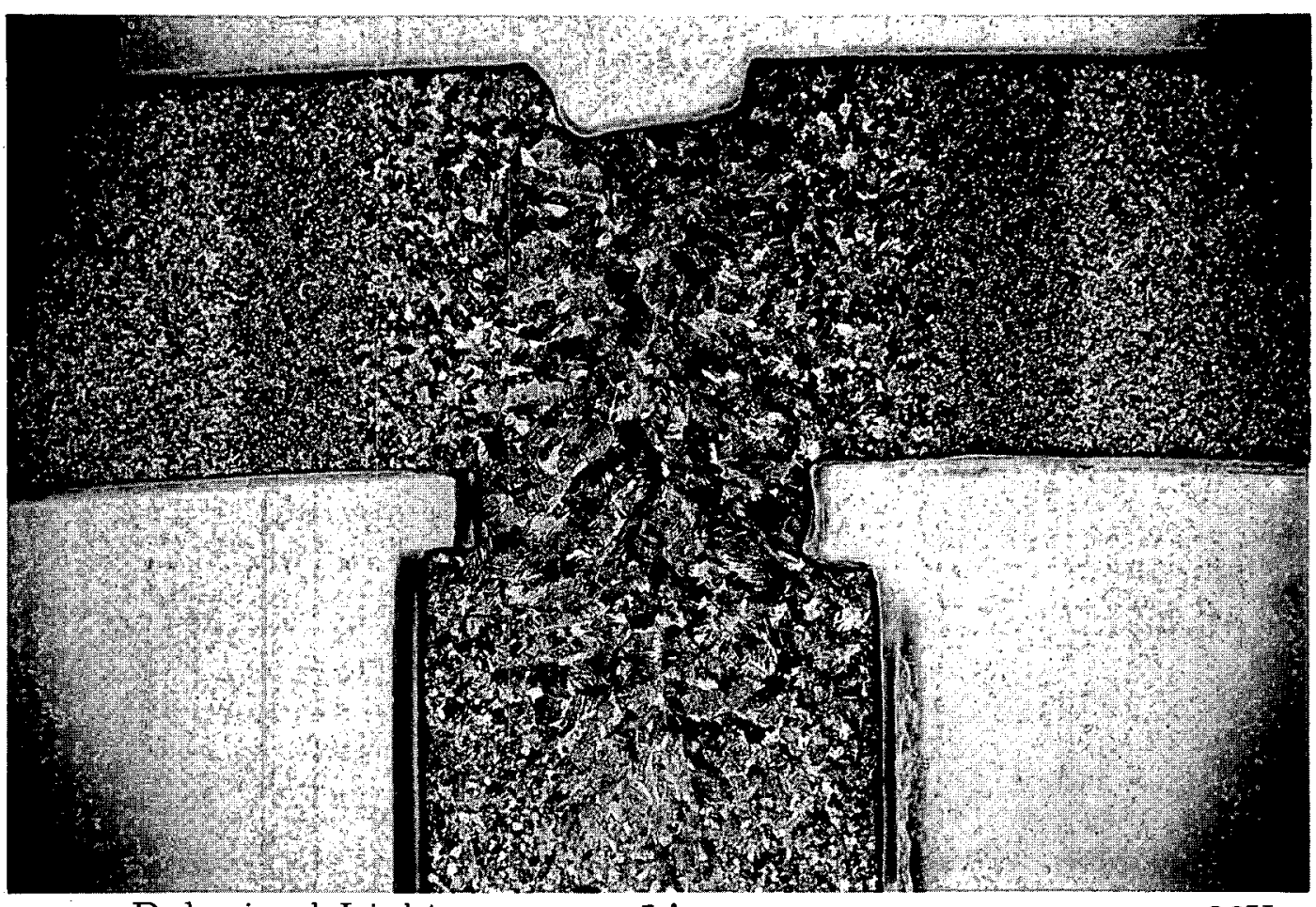

Polarized Light

$5 \mathrm{~A}$

$32 \mathrm{X}$

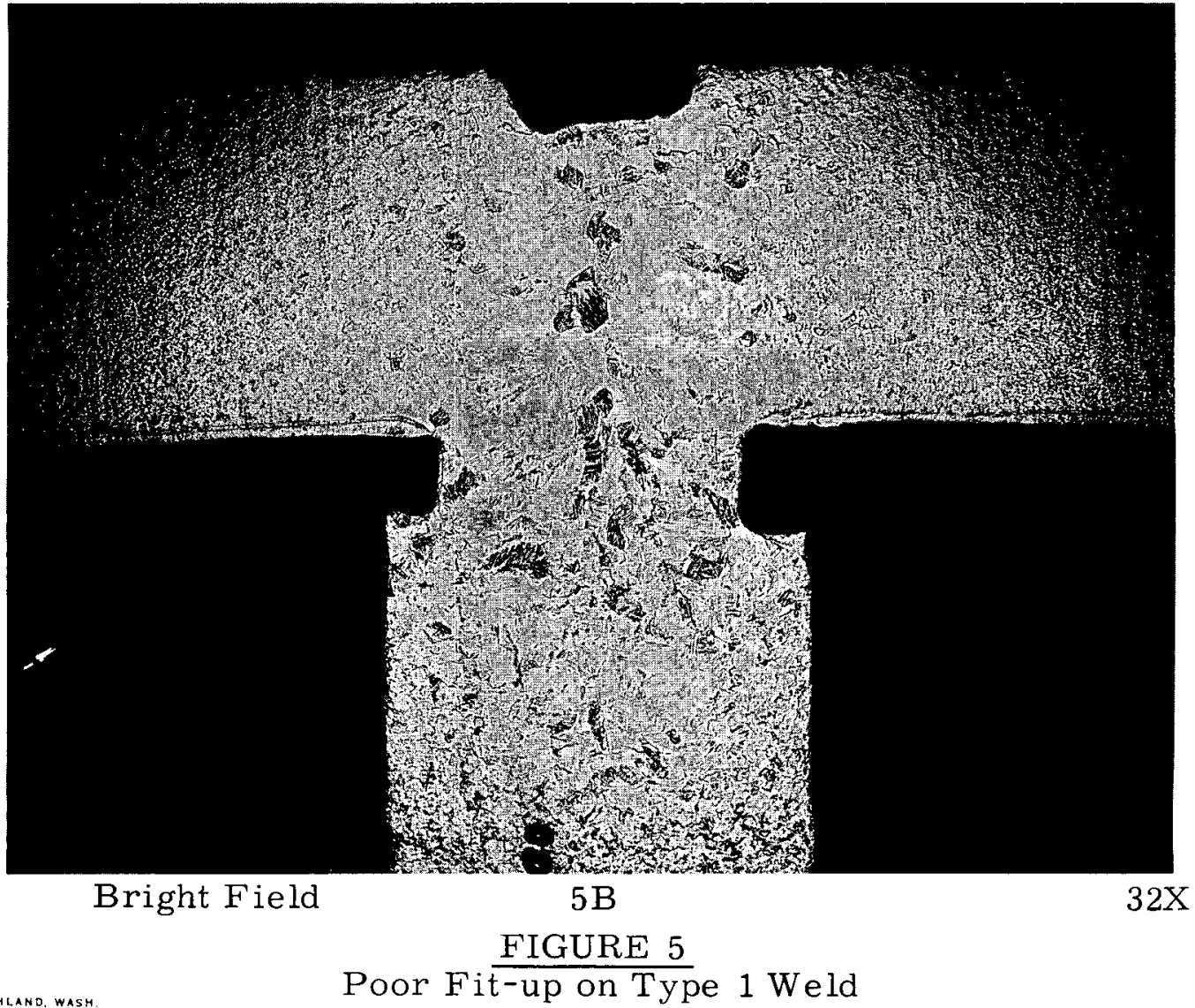




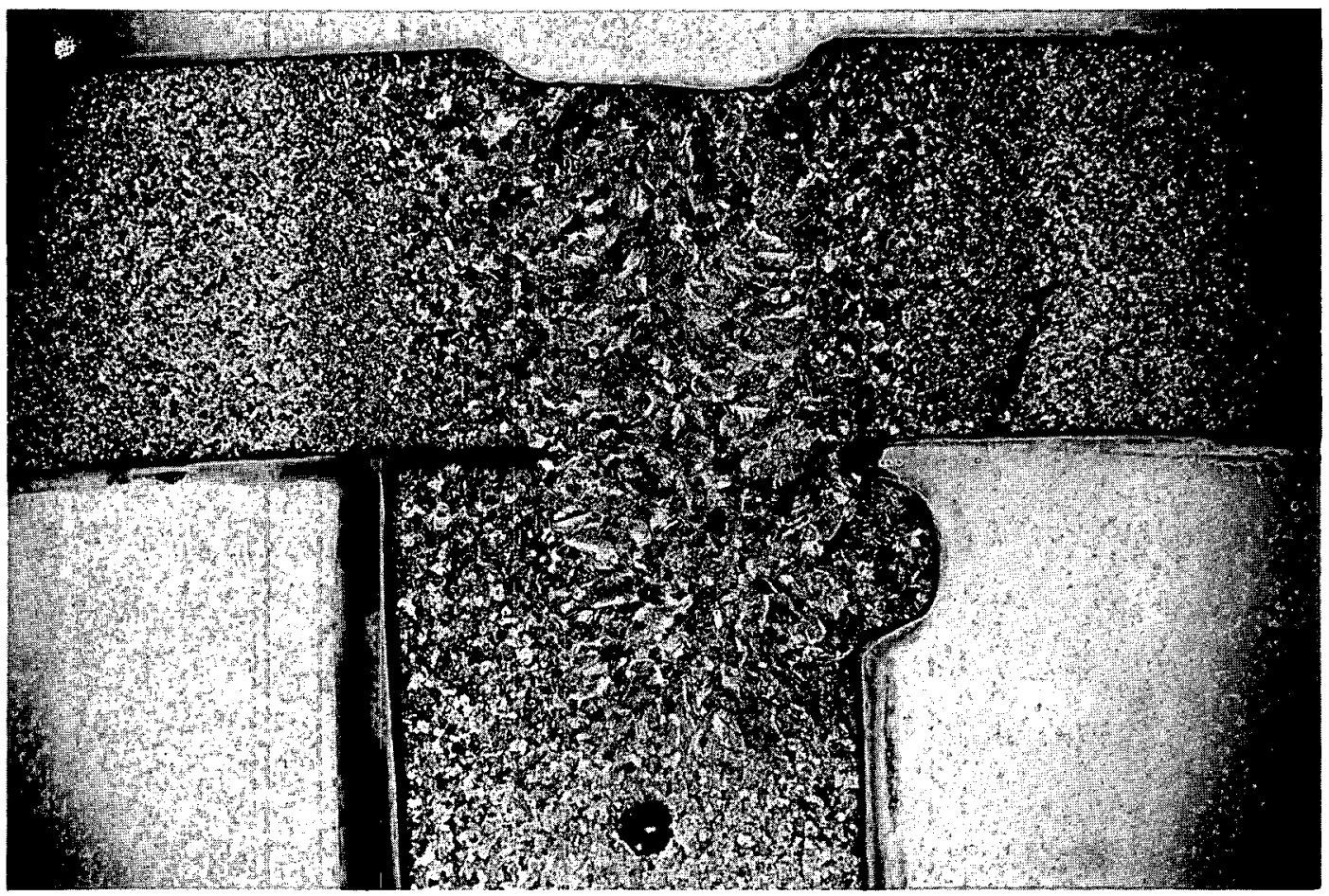

Polarized Light

$$
\text { FIGURE } 6
$$

Type 1 Weld with Electron Beam Penetration to one Side of Rib

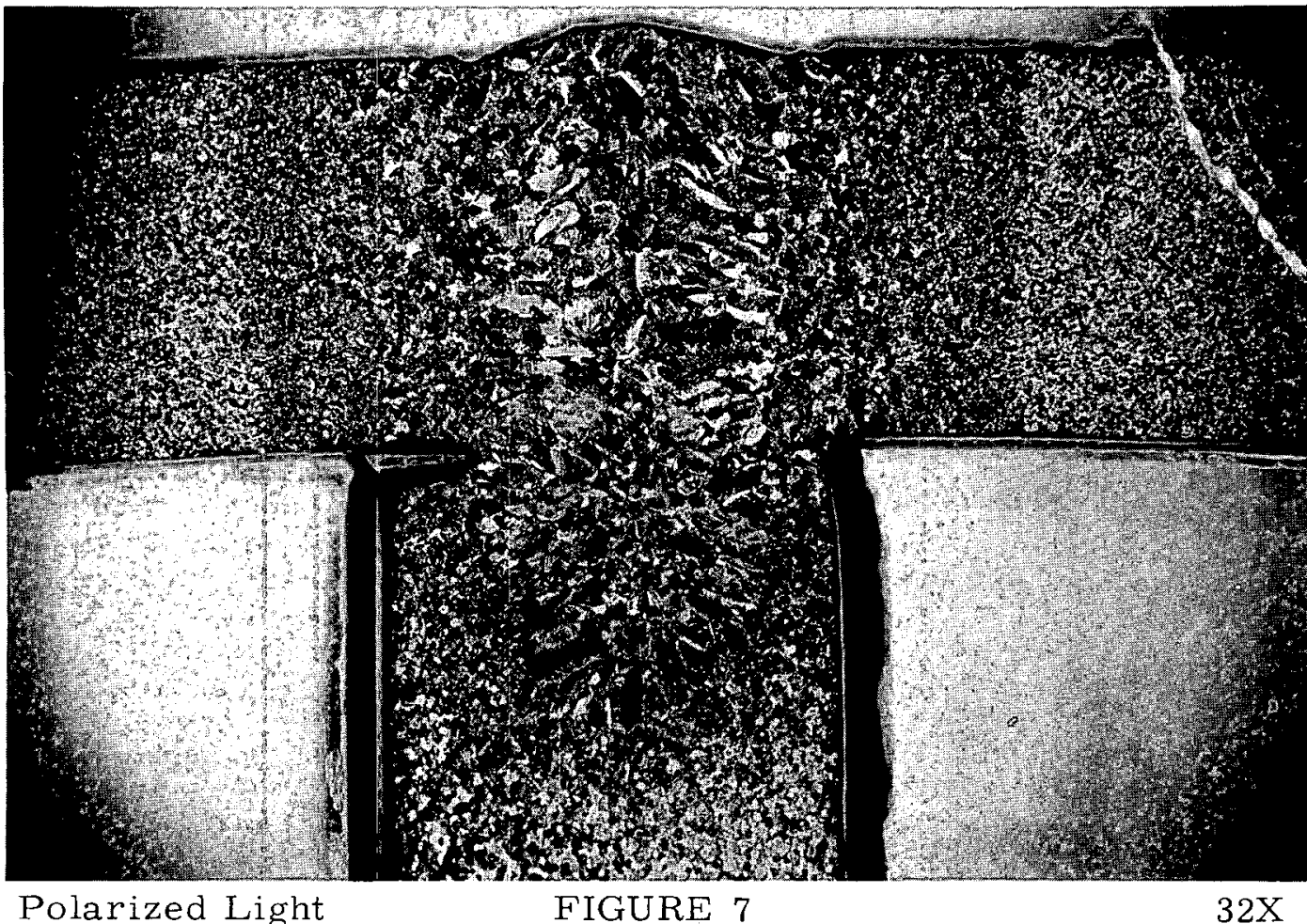

An Acceptable Type $1 \mathrm{Weld}$ 
Type 2 Weldments

This is a joint fabricated by aiming the beam tangentially to the cylindrical cladding and toward the point of contact between the rib and tube. One weld pass is made on each side of the rib to assure complete penetration and to eliminate the rough surface that would occur on the root side of the weld if single-pass full penetration were employed.

Figures 8, 9A, and 9B show a typical joint section. Figure 8 indicates that the electron beam has a tendency to curve in this particular type of joint. The welds from both sides of the rib curve toward the top of the rib. The mechanism of this phenomenon is not known; however, the shape of the part apparently affects the electron beam.

A welded joint with incomplete penetration of the electron beam on both sides of the rib is shown in Figure 10 .

Figures $9 \mathrm{~A}$ and $9 \mathrm{~B}$ illustrate the type of weld quality acceptable for nuclear fuel elements. The heat affected zone is narrow and there is complete penetration. Undercutting of the rib is slight with a smooth contour, and there is no porosity in this section. Porosity is occasionally encountered with this joint as shown in Figure 11.

Type $3 \mathrm{~W}$ eldments

This is a joint comprised of a burn-through weld between two tubes with a small tube in contact with the ID of a large tube. The electron beam initially impinges on the large tube and penetrates into the smaller tube to form the weld.

A normal weld of this joint type is illustrated in Figures $12 \mathrm{~A}$ and 12B. The electron beam appears to have initially impinged on a point of the large tube that was directly above the point of contact of the two tubes. The fit between the tubes was good and the beam did not penetrate to the inside of the small tube. 


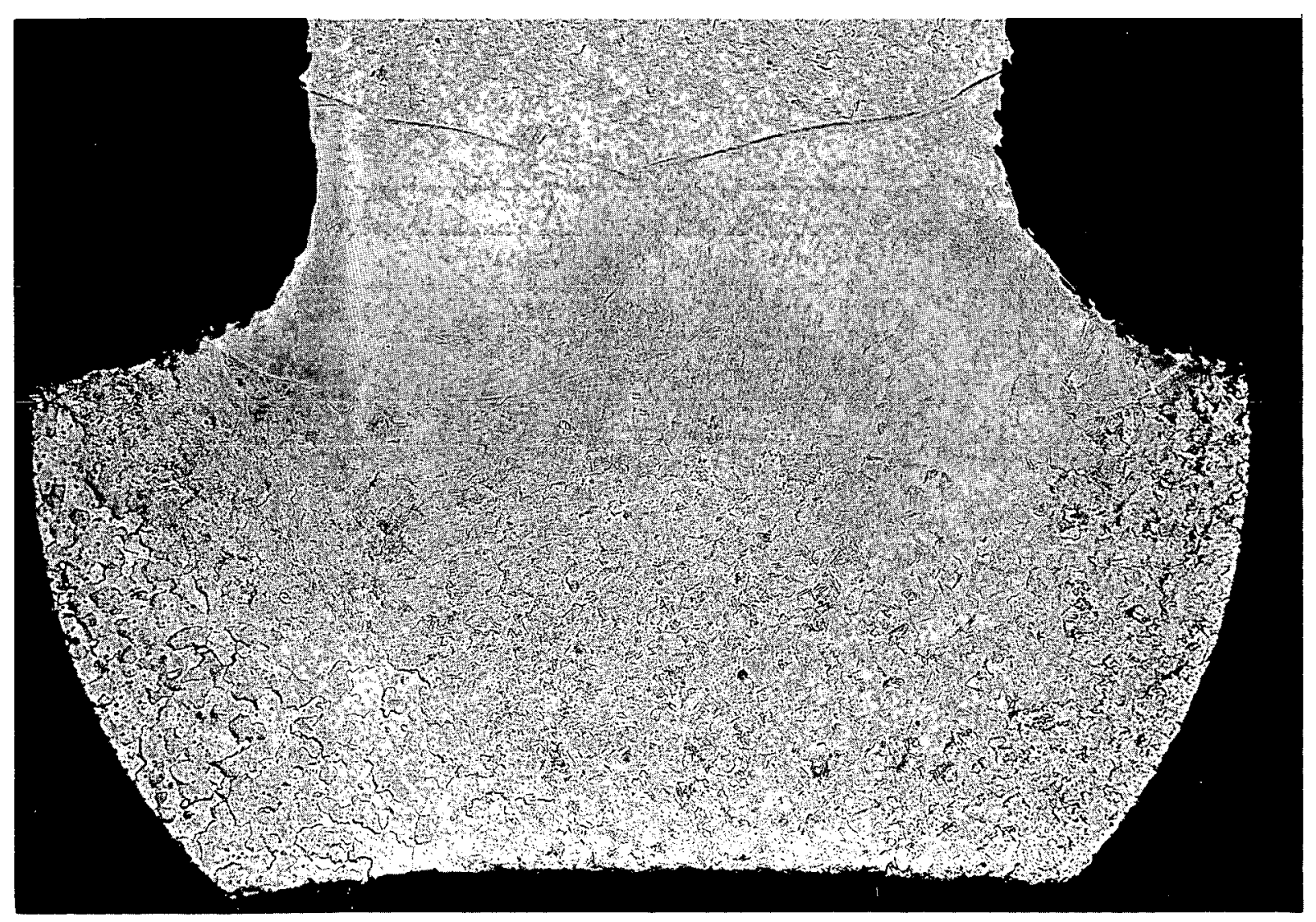

Bright Field

FIGURE 8

A Good Type 2 Weld

$50 \mathrm{X}$

焉

$\sum_{1}^{1}$

零 


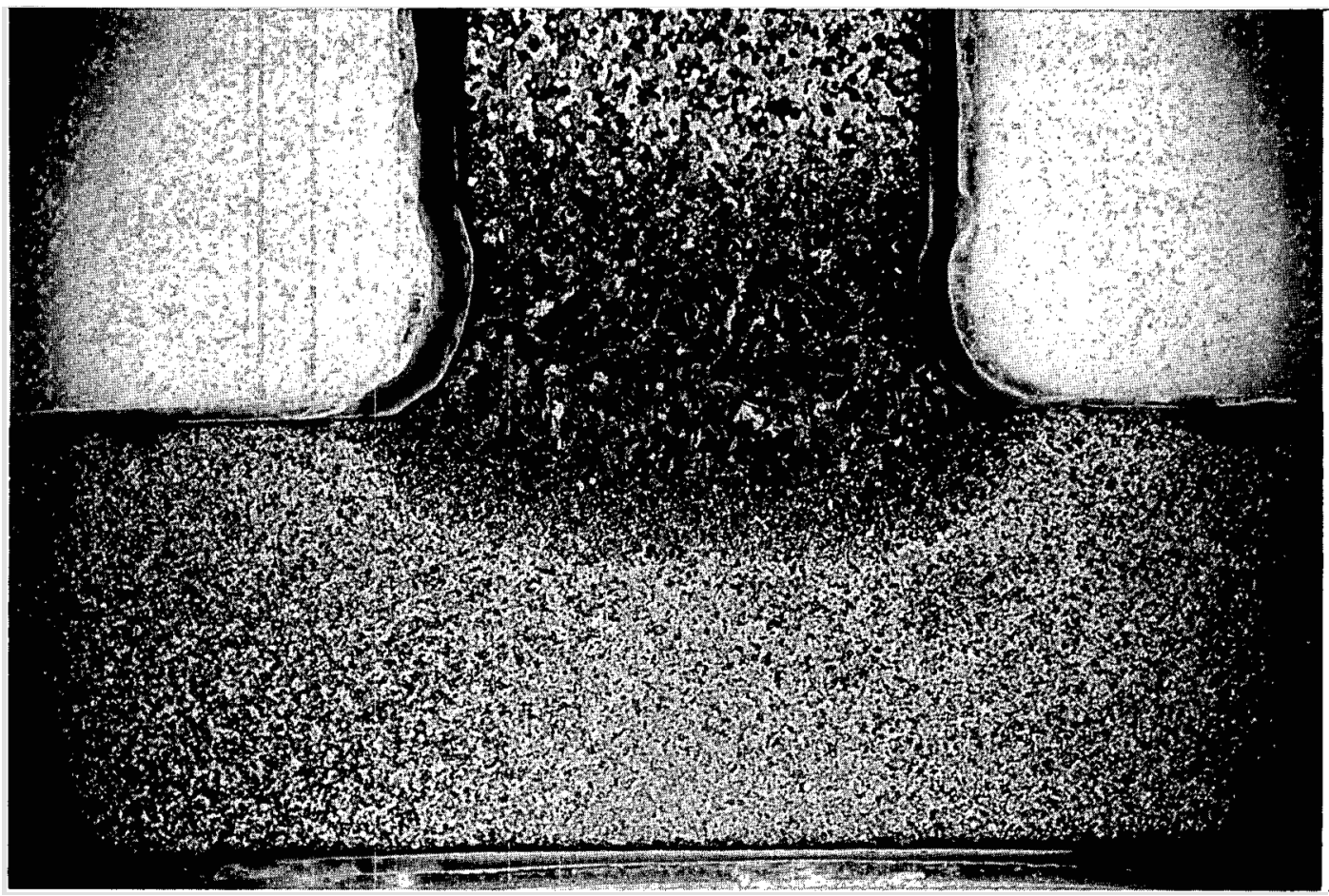

Polarized Light

$9 \mathrm{~A}$

$32 X$

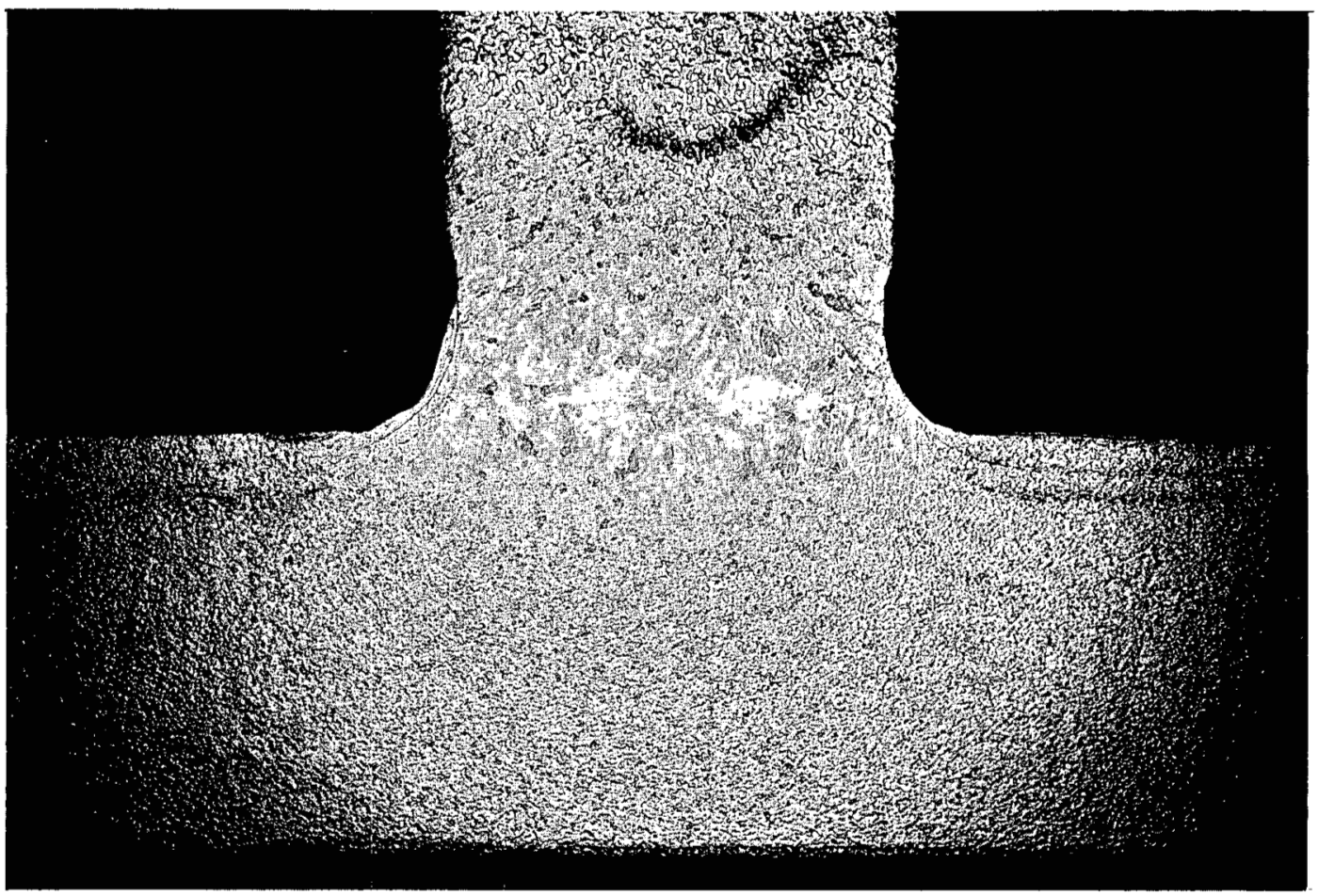

Bright Field

9B

$32 \mathrm{X}$

FIGURE 9

A Good Type 2 Weld 


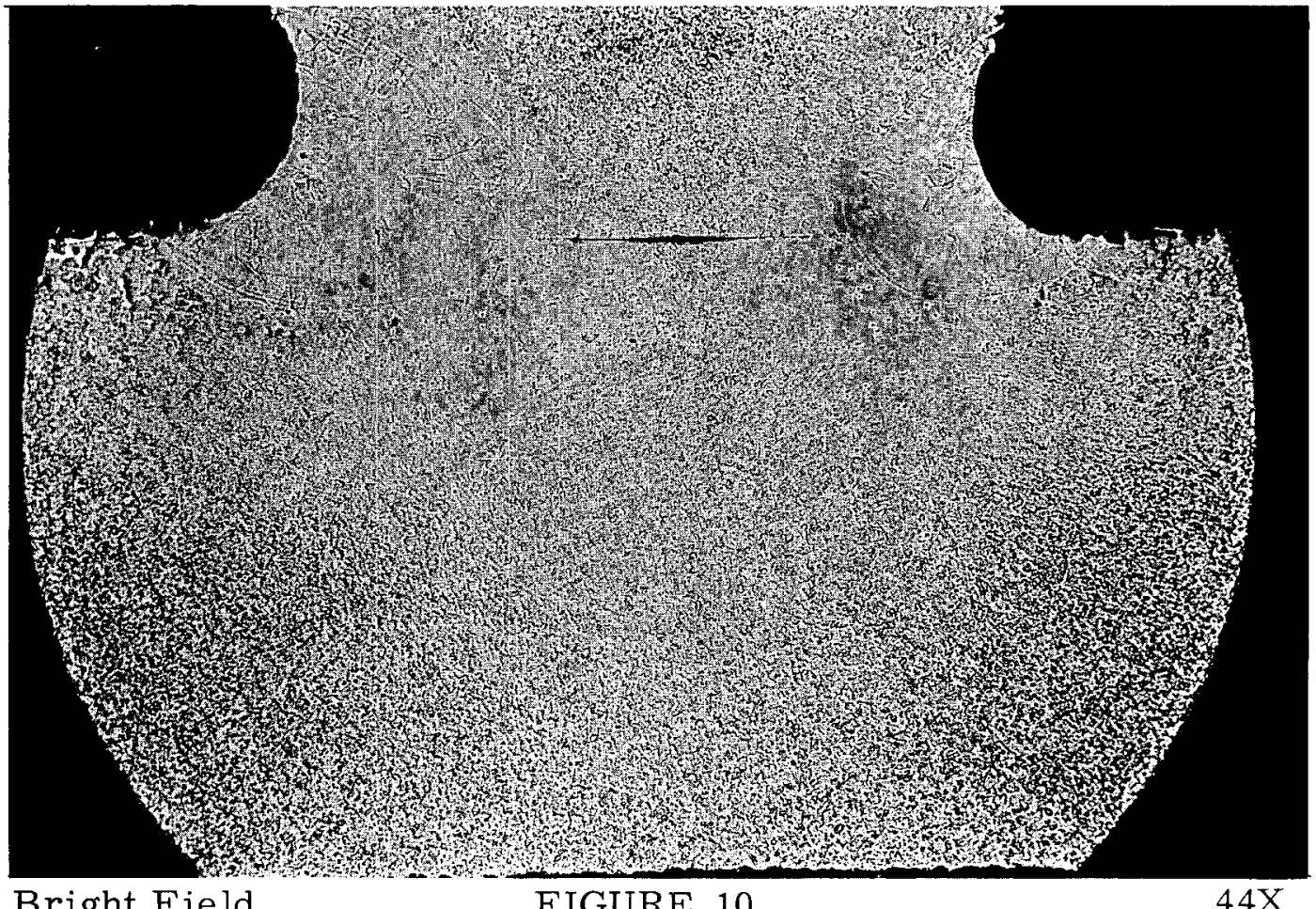

Incomplete Penetration on a Type 2 Weld

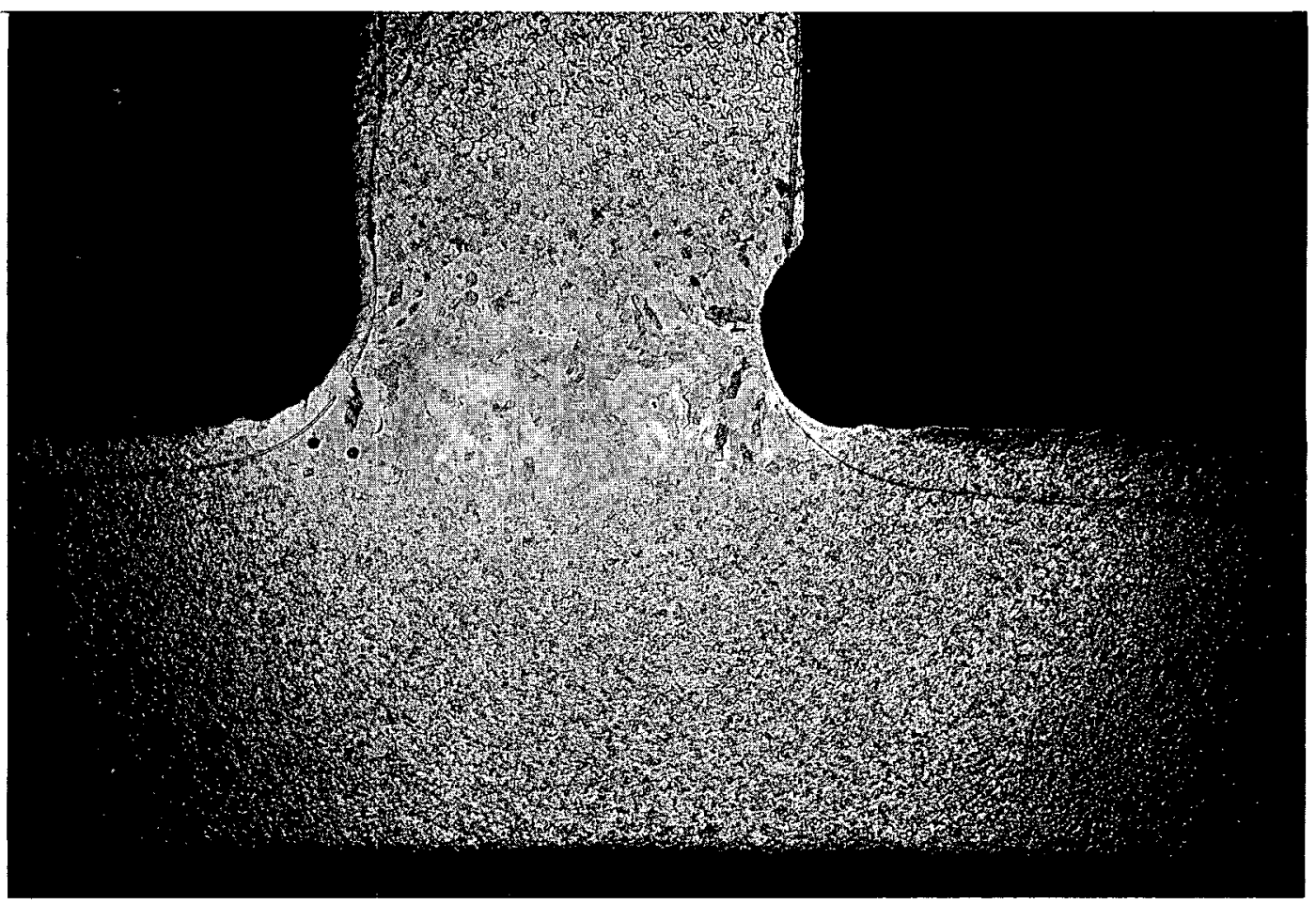

Bright Field

FIGURE 11 

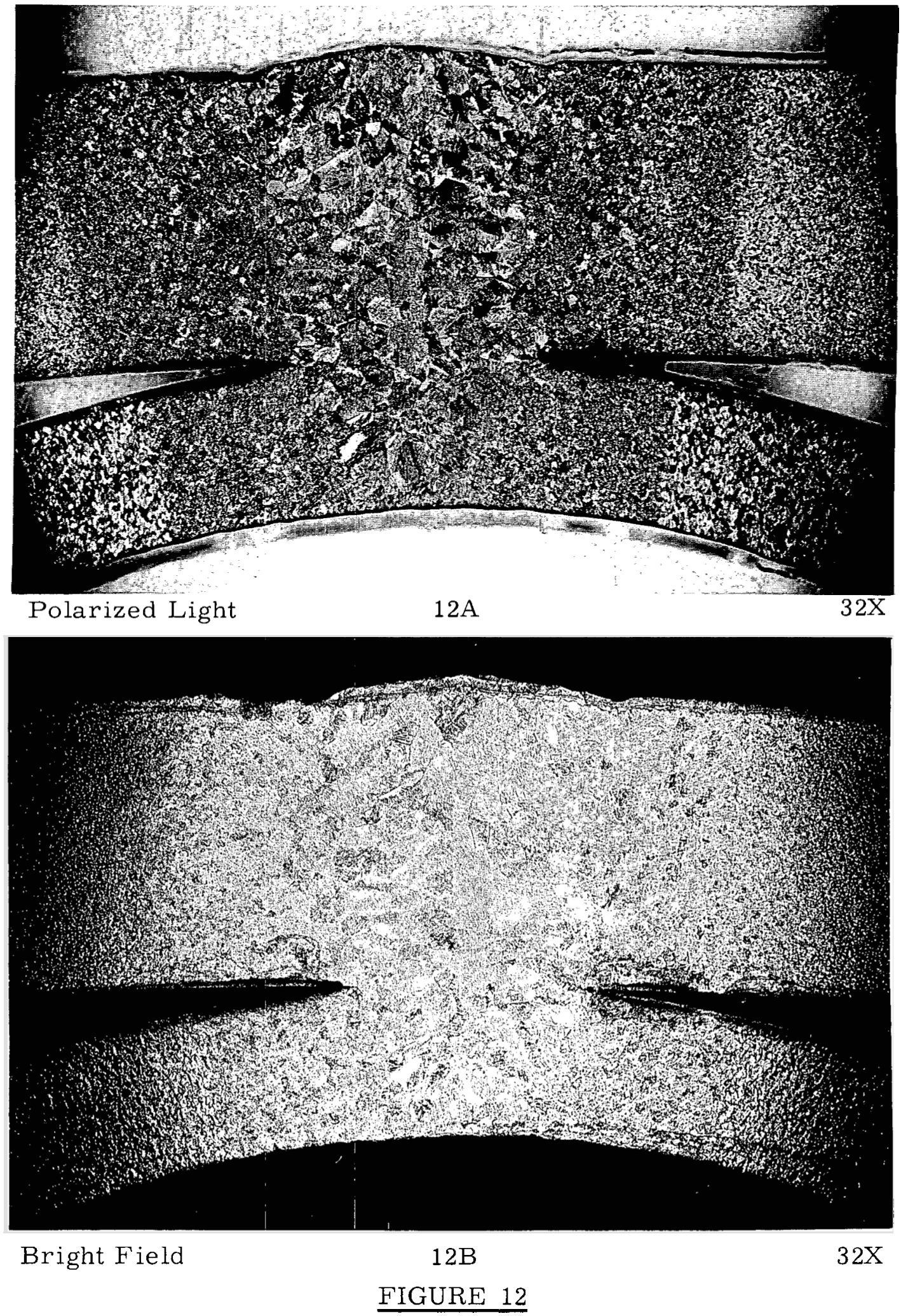

A Good Type 3 Weld 
Figures $13 \mathrm{~A}$ and $13 \mathrm{~B}$ show the results of excessive penetration and poor fit. Excessive penetration results in irregular protrusions on the inside of the small tube which are difficult to remove but do not affect the integrity of the weld.

A close fit between the two tubes may or may not be desirable, depending on the ultimate use of the assembly. The photomicrograph shows a gap between tubes of approximately 0.01 inches. A successful weld may be made with a much greater gap, but the optimum gap width is dependent on the width of the weld and the size of the groove at the top of the weld that can be tolerated.

An interesting distribution of porosity is apparent in Figure $13 \mathrm{~A}$ and will be discussed later.

Type 4 Weldments

Two small tubes, laid side by side, can be joined using either one pass or a pass on each side of the joint. Since the metal to fill the joint comes from the walls of the tubes, a close fit between the pieces is essential to prevent wall thinning. With greater spacing, more metal will have to be taken from the walls to fill the joint. This situation will result in a reduced tube wall thickness.

Figure 14 is an illustration of a typical two-pass weldment of this type.

Figures 15 and 16 show the one-pass joint. Figure 15 is an acceptable weld, while the joint in Figure 16 has insufficient penetration.

Figures 17 and 18 show porosity in the two-pass and one-pass welds, respectively.

\section{Type 5 Weldments}

This round wire-to-tube joint is extremely difficult to achieve. The point of beam impingement and the path of beam penetration have to be carefully selected in order to minimize melting of the wire and 


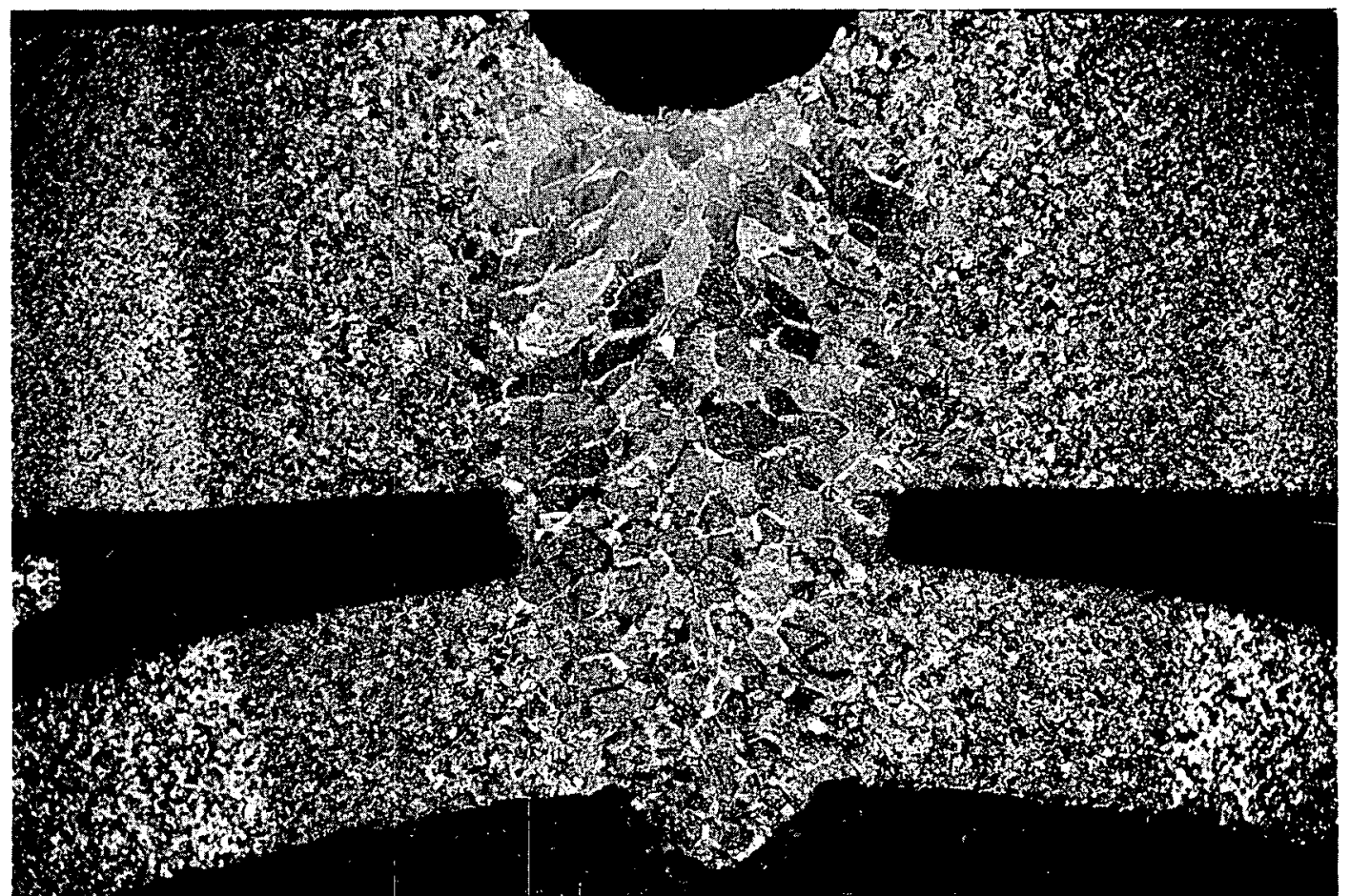

Polzrized Light

$13 \mathrm{~A}$

$32 X$

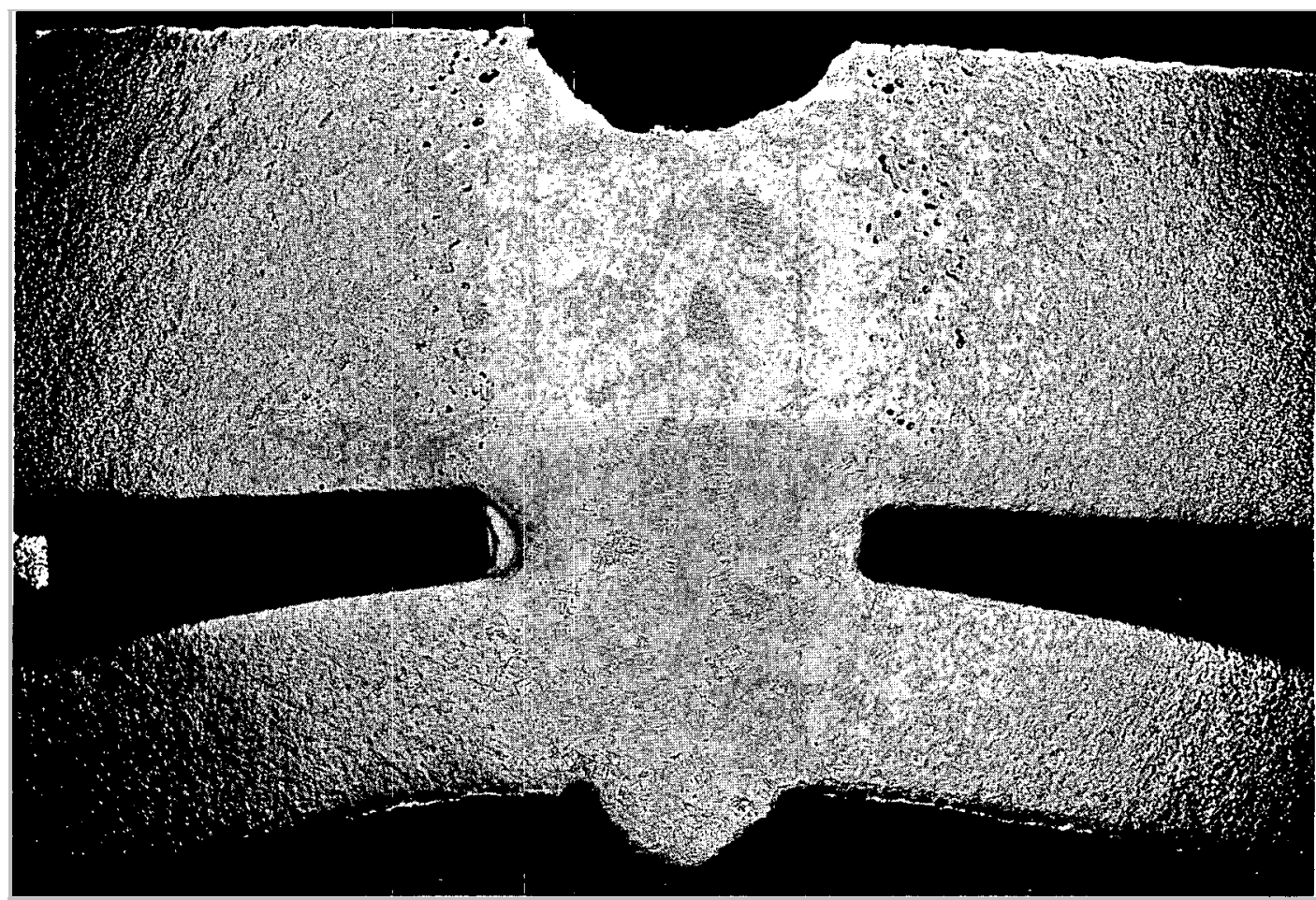

Bright Field

FIGURE 13

Excessive Penetration and Poor Fit on Type 3 Welds 


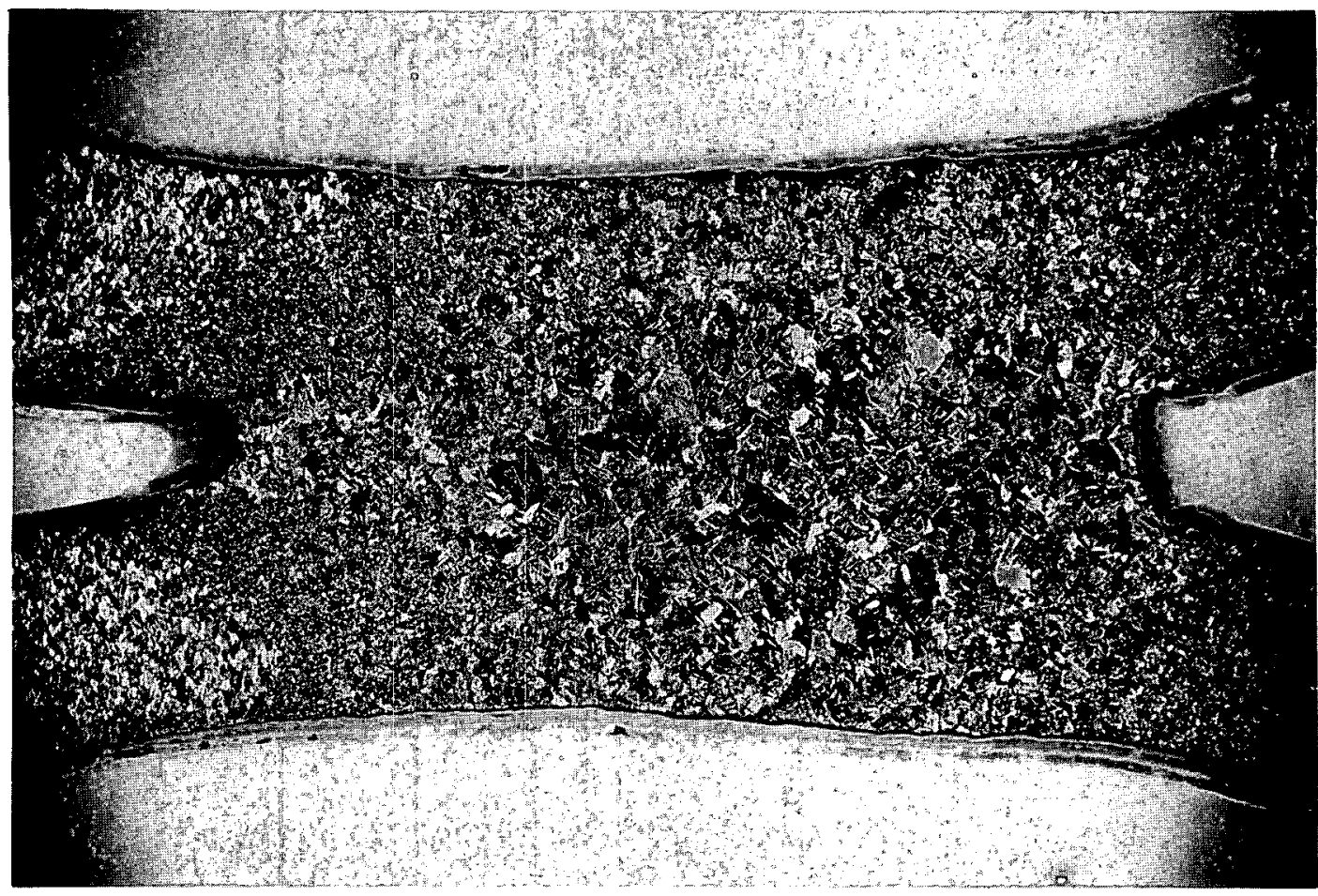

Polarized Light

FIGURE 14

A Good Two-Pass Type 4 Weld

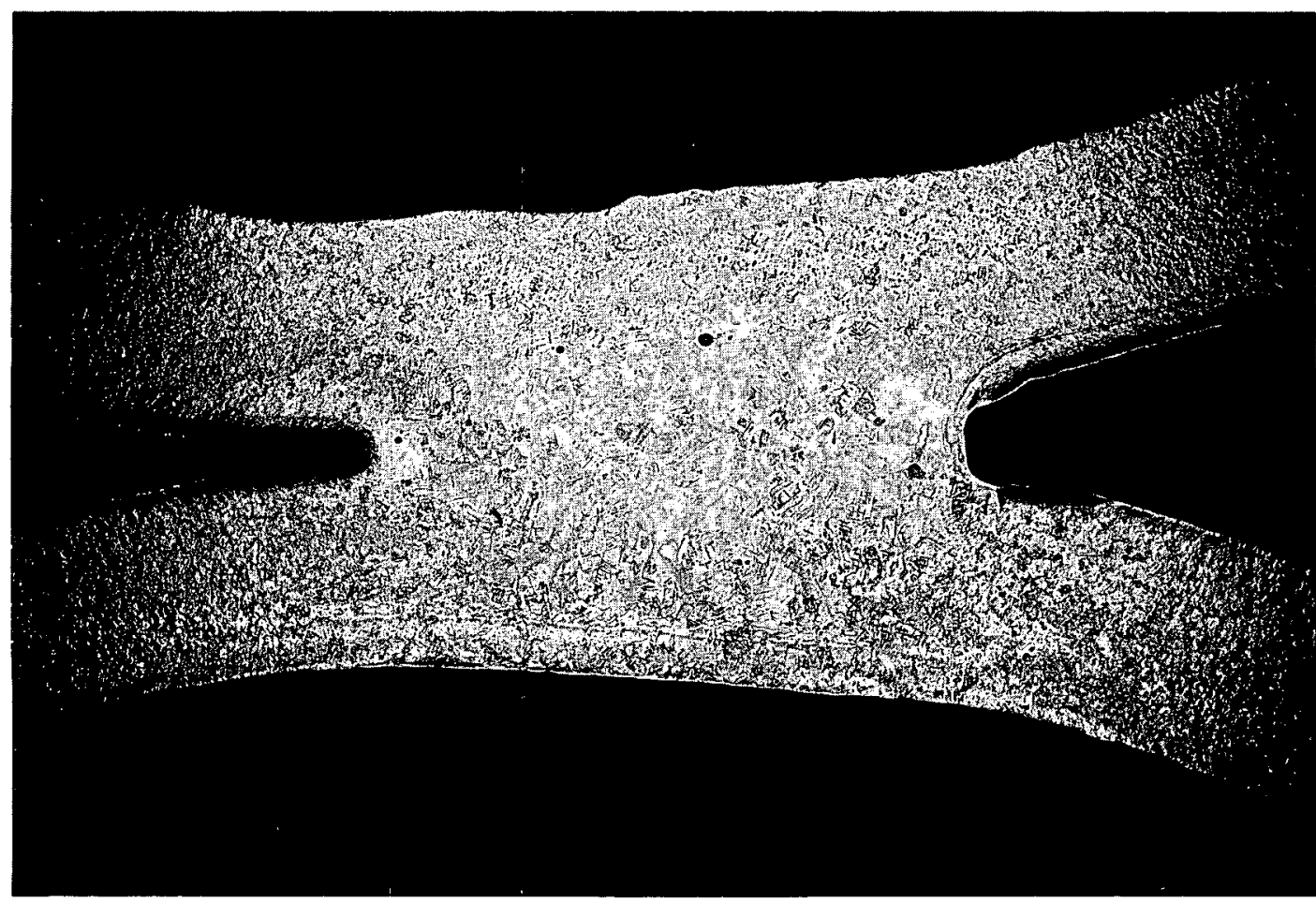

Bright Field

FIGURE 15

$32 X$

A Good One-Pass Type 4 Weld 


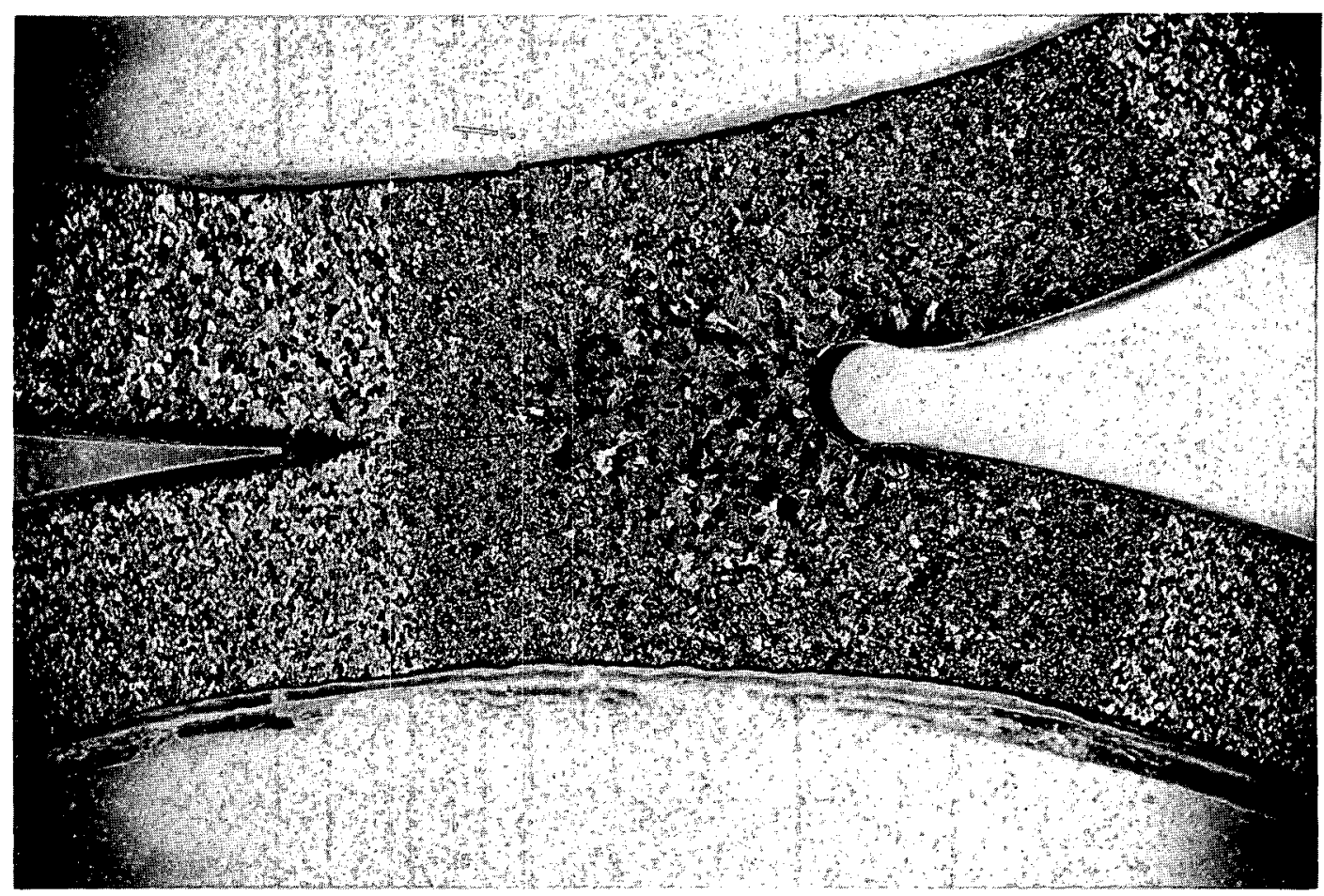

Polarized Light FIGURE 16

$32 X$

One-Pass Type 4 Weld Showing Insufficient Penetration

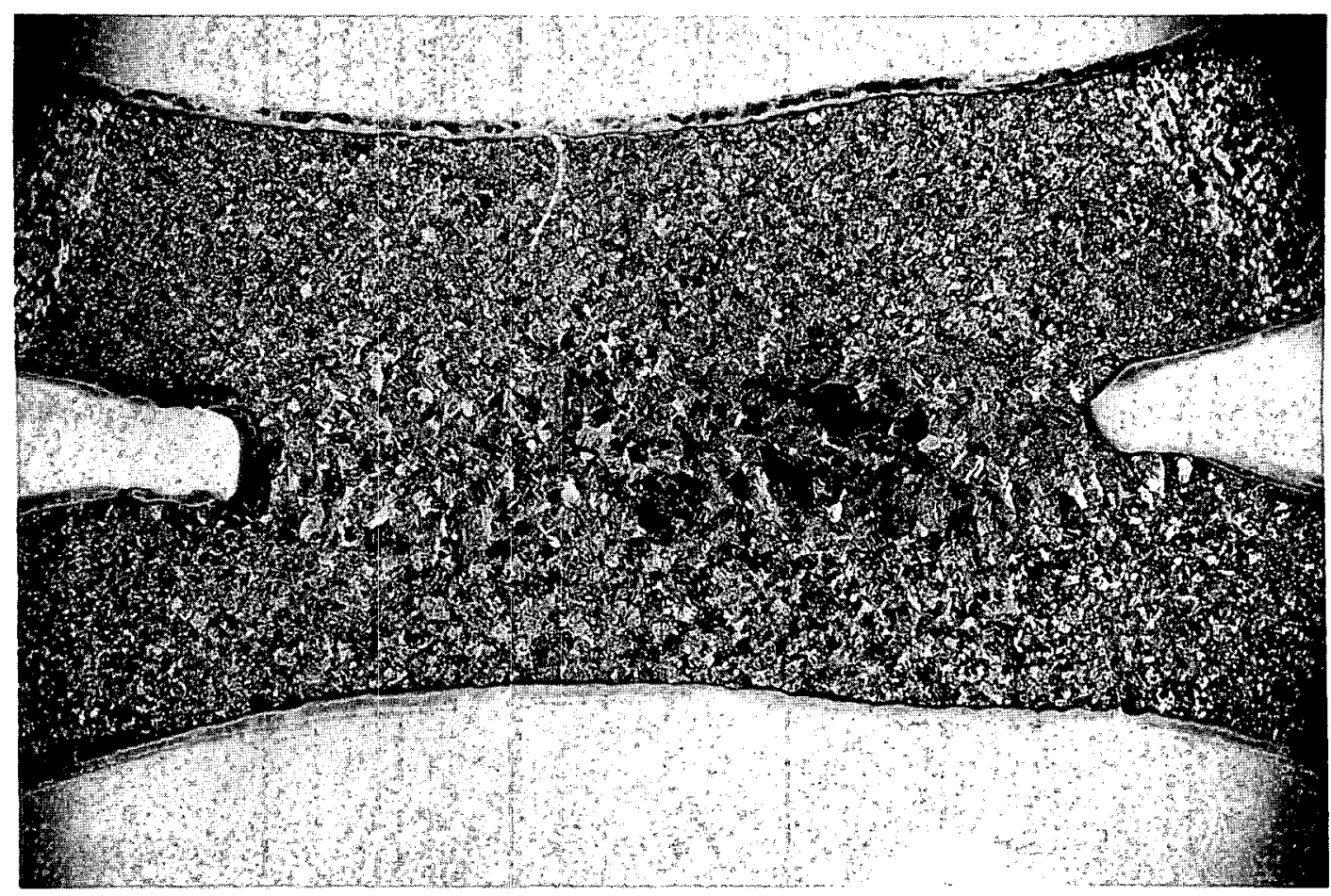

Polarized Light

FIGURE 17

$32 \mathrm{X}$

Two-Pass Type 4 Weld Showing Porosity 


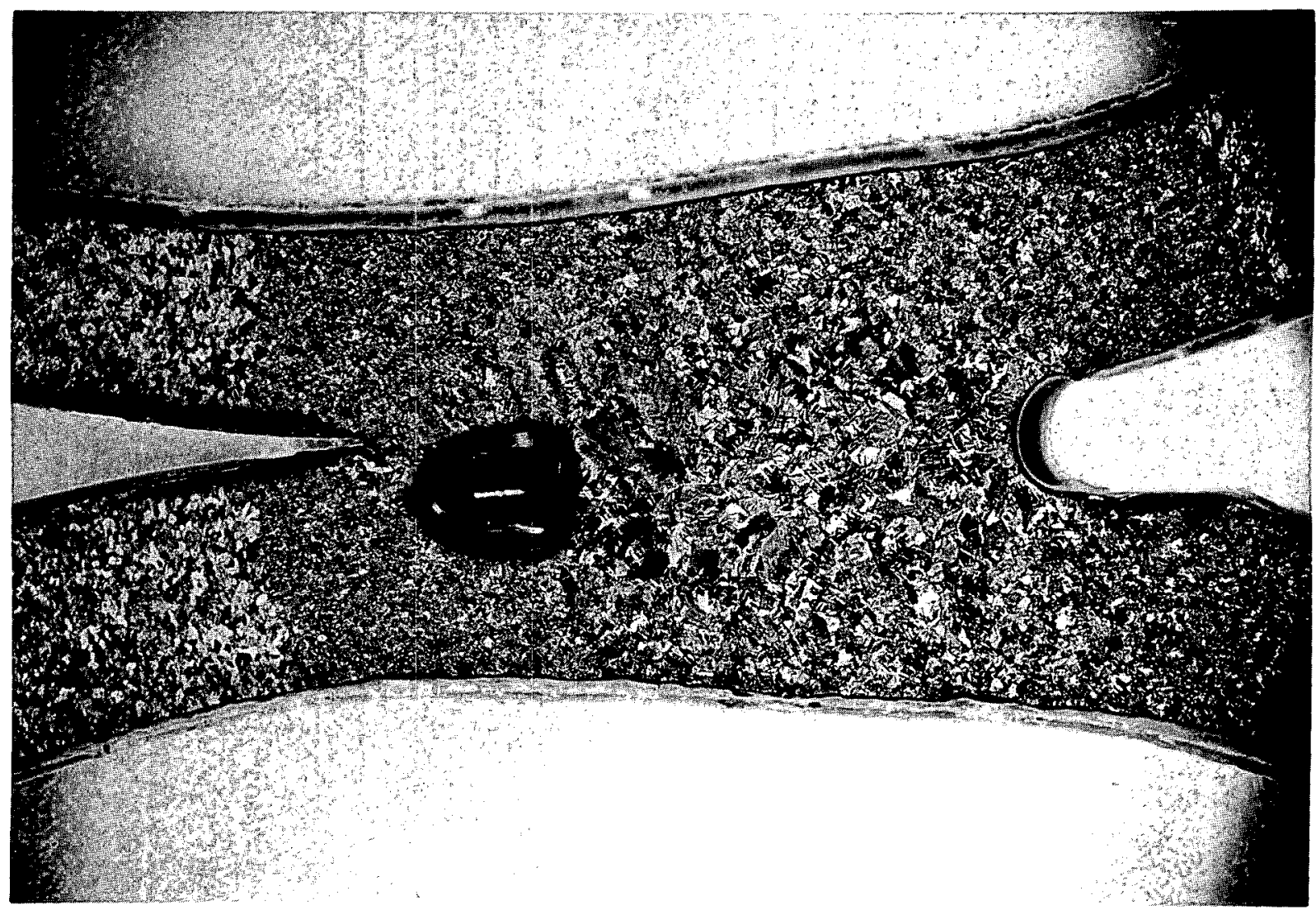

Polarized Light

FIGURE 18

$36 \mathrm{X}$

One-Pass Type 4 Weld Showing Porosity

tube. In addition, extreme caution is required to prevent undercutting of the tube. Figures $19 \mathrm{~A}$ and $19 \mathrm{~B}$ are cross sections of a weld. Because of point contact between the wire and tube, metal to fill the joint must be obtained from either the wire or the tube. In most cases, the metal should be taken from the wire to eliminate tube wall thinning. If an assembly is to be made from a group containing joints of this type, dimensional changes should be anticipated. 

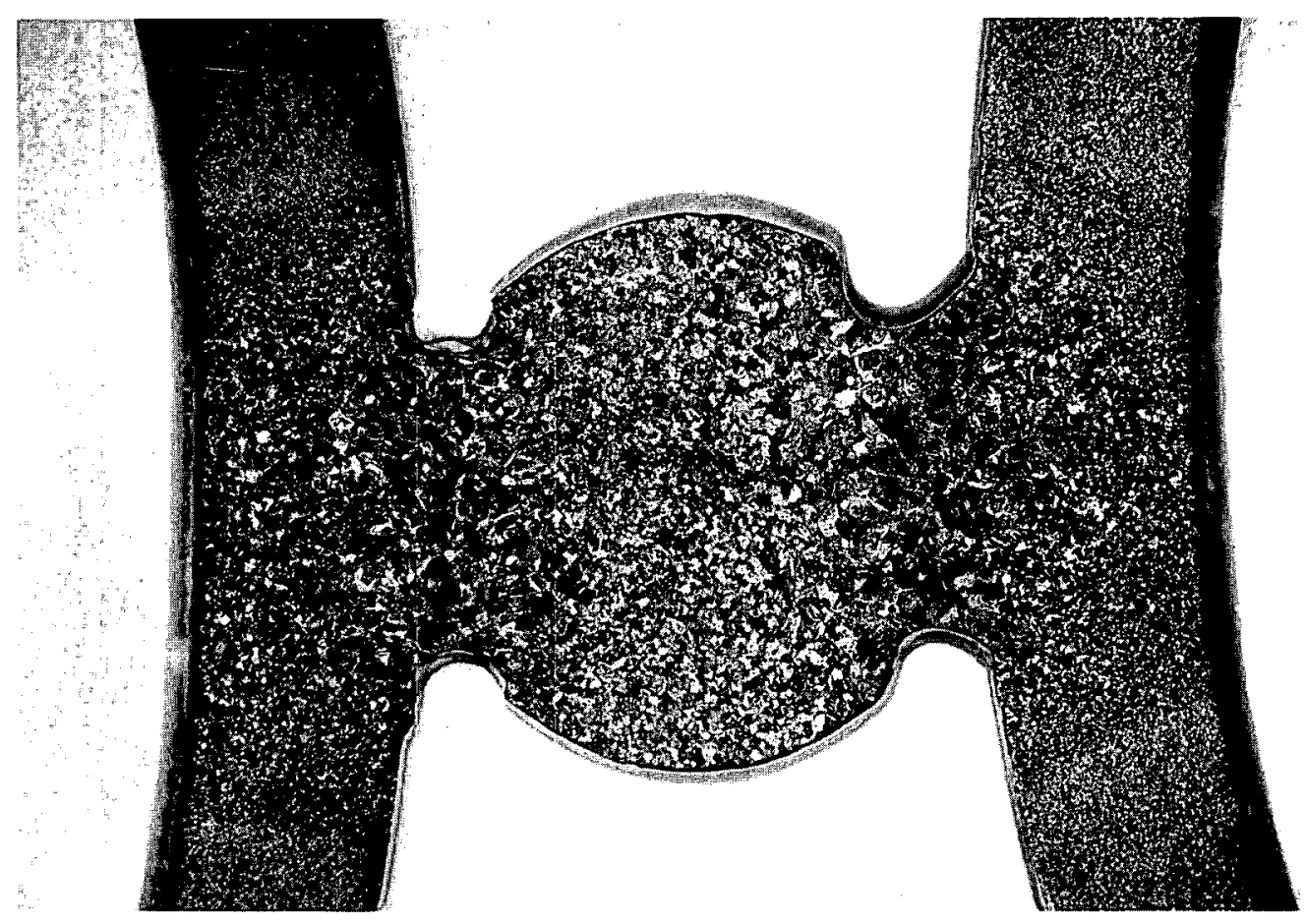

Polarized Light

$19 \mathrm{~A}$

$32 \mathrm{X}$

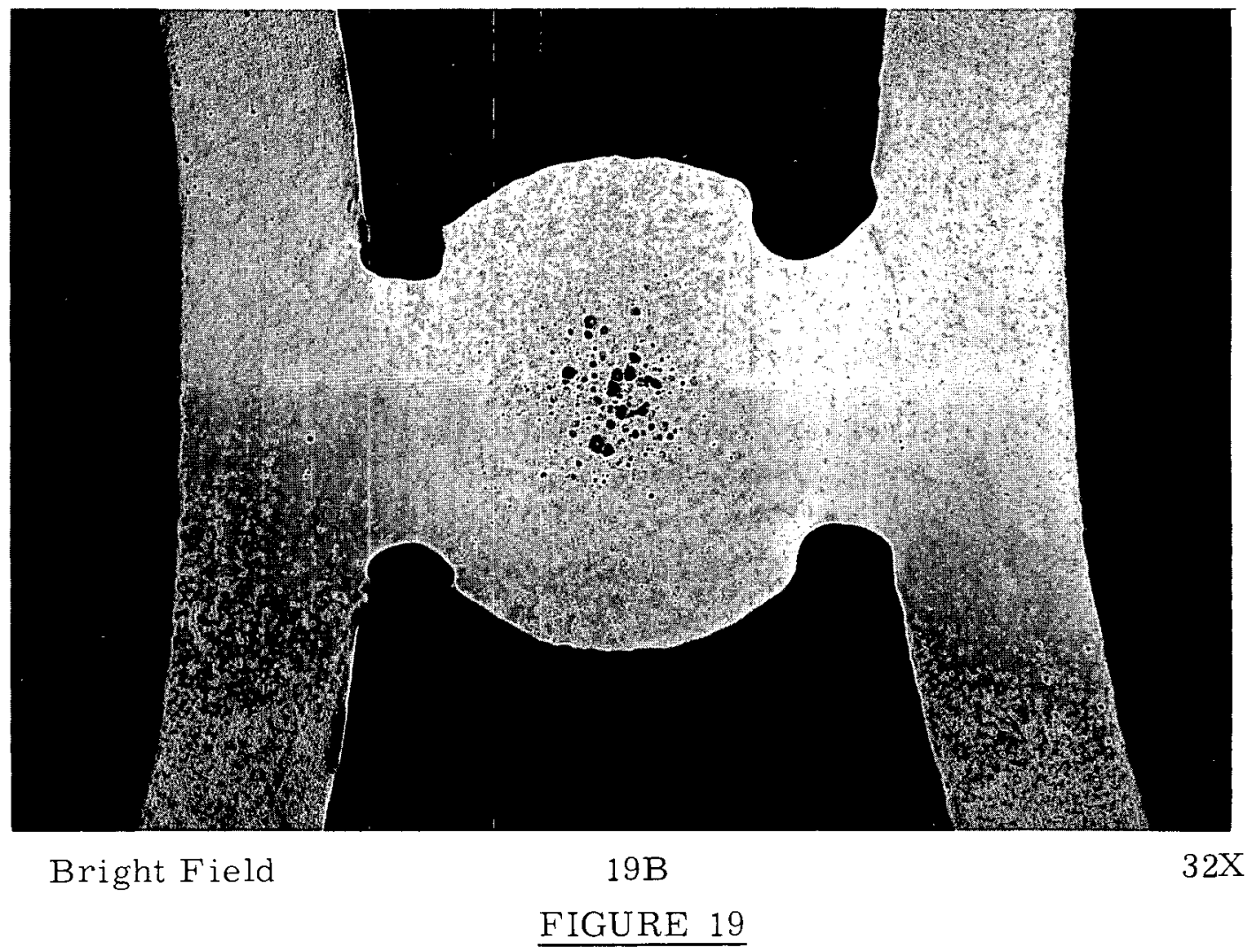

Type $5 \mathrm{Weld}$ 
Figure 20 is a photomicrograph of a longitudinal section of Type 1 and 2 joints. Joint 1 is at the top of the photograph and joint 2 at the bottom. Note the grain structure in the Type 2 joint. The direction of travel of the welding beam is clearly discernible. The apparent line near the bottom of the photo, in the Type 2 joint, indicates the center of the melt with the electron beam coming from a direction perpendicular to the plane of the paper and traveling from right to left. Figure 21 is an enlarged portion of this section.

Figure 22 and Figure 23 are longitudinal photomicrographs of joints 3 and 4 , respectively.

Weld Joint Porosity

Very little mention of porosity has been made in the preceding paragraphs. This is because the porosity in all joints has much in common. The small porosity, with but few exceptions, occurred along the edges of the melts. The large holes which were found only in Type 4 weldments always appeared near the point of maximum beam penetration.

Porosity is attributed to impurities in the materials used and not to the electron beam welding process.

Welding Parameters

Table II lists the parameters for the electron beam welding of the various weld types.

\section{TABLE II}

\section{WELDING PARAMETERS}

\begin{tabular}{cc} 
Weld & $\begin{array}{c}\text { Accelerating } \\
\text { Potential } \\
\text { Type }\end{array}$ \\
\cline { 1 - 2 } 1 & 100 \\
2 & 100 \\
3 & 100 \\
4 & 90 \\
5 & 80
\end{tabular}

\begin{tabular}{cc}
$\begin{array}{c}\text { Electron } \\
\text { Beam Current } \\
\text { (ma) }\end{array}$ & $\begin{array}{c}\text { Speed } \\
\text { of Travel } \\
\text { (in./min) }\end{array}$ \\
\hline 6 & 50 \\
3 & 30 \\
4.5 & 30 \\
3 & 30 \\
2.5 & 30
\end{tabular}




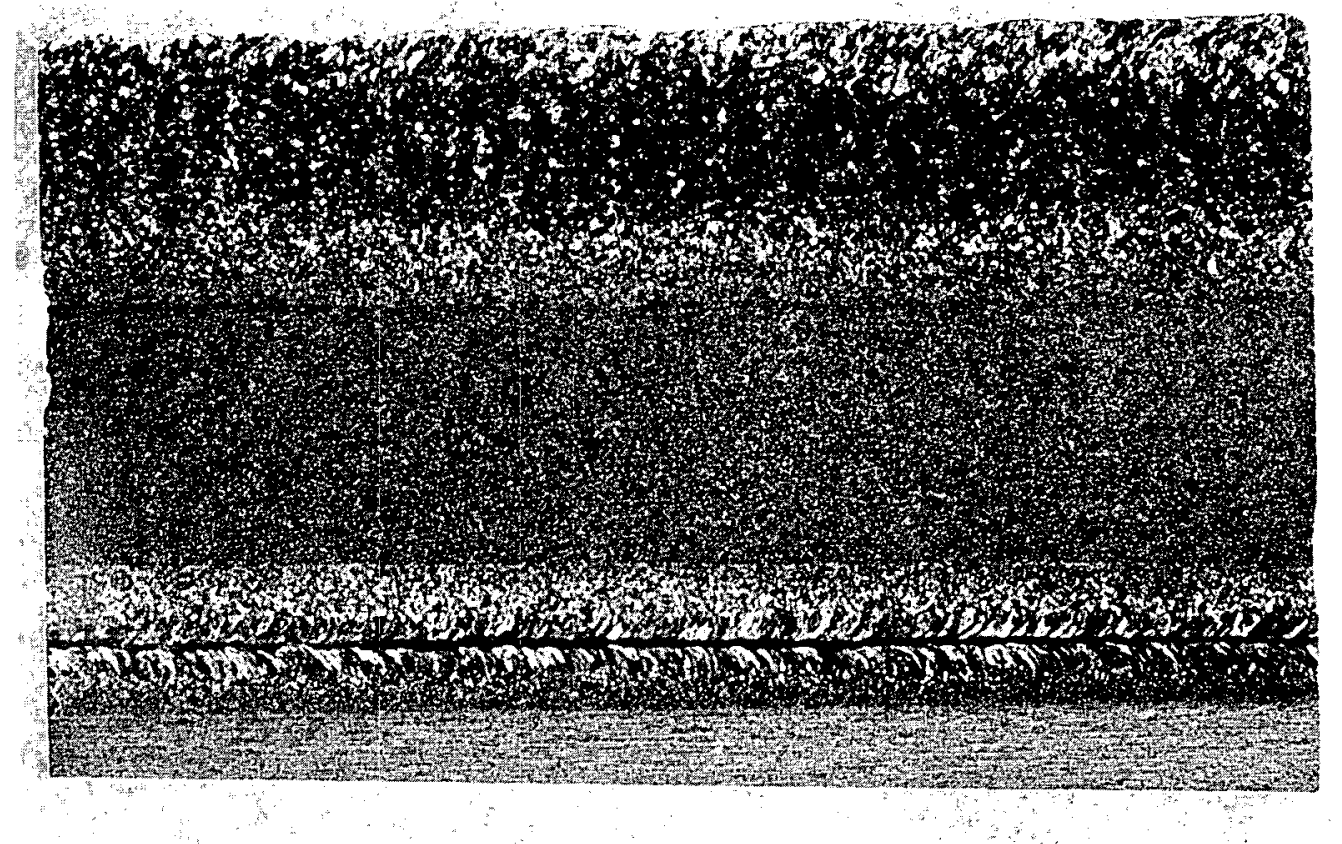

FIGURE 20

$11 \mathrm{X}$

Longitudinal Section of Type 1 and Type 2 Joints

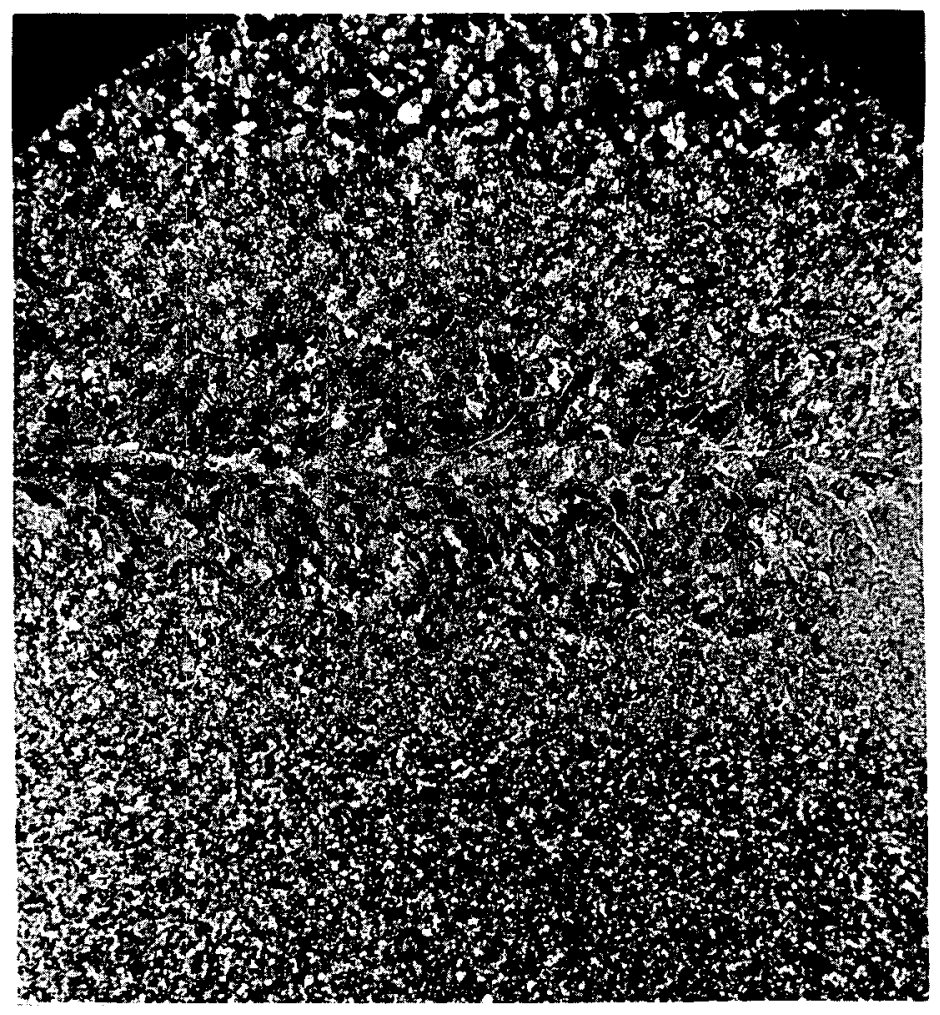

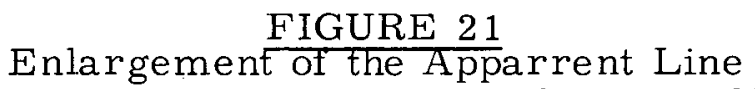




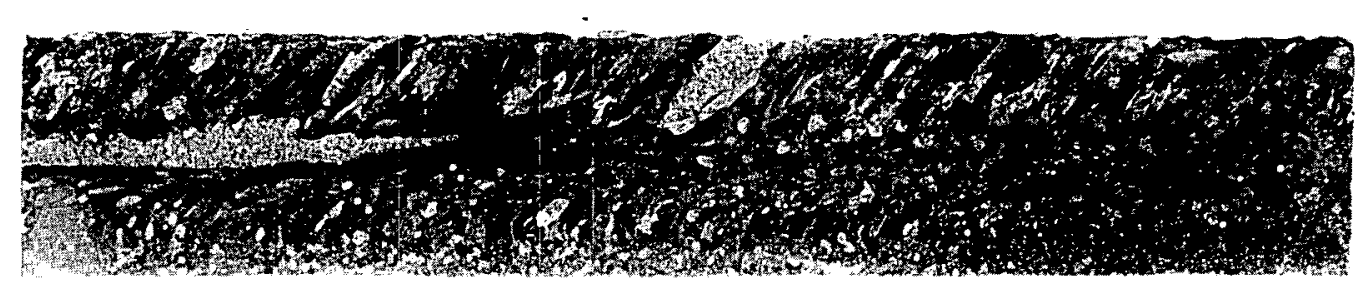

FIGURE 22

$11 \mathrm{X}$

Longitudinal Section of Type 3 Joint

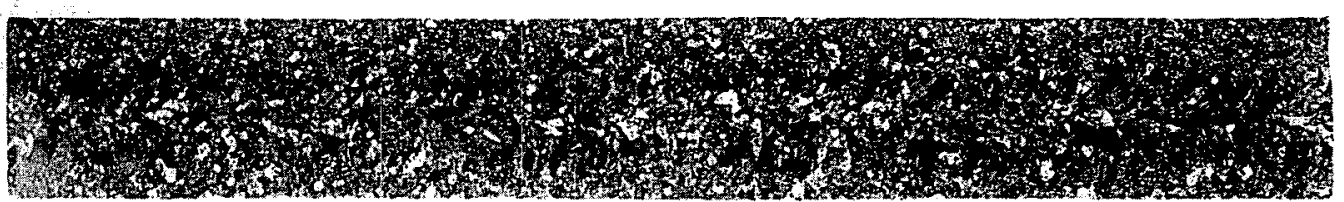

FIGURE 23

$11 \mathrm{X}$

Longitudinal Section of Type 4 Joint 


\section{CONCLUSIONS}

The electron beam welding process has proven highly successful for fabricating fuel element claddings having either standard or unusual configurations. The success of initial trials prompted the fabrication of actual pieces of cladding, using the full $9 \mathrm{ft}$ long tubes. Photographs of these pieces may be seen in Figure 24, which shows a preassembled 19 -rod cluster and a tube-in-tube cladding assembly, and Figure 25. which shows spacer ribs attached to the nested tubular cladding parts.

Figures 26 and 27 are additional experimental configurations that illustrate versatility of the electron beam welding process.

\section{ACKNOW LEDGMENT}

The author expresses his appreciation to these people for assisting in the preparation of this report: L. E. Mills, for his invaluable technical assistance and consultation; R. F. Boolen, who prepared the parts for welding; L. A. Hartcorn, for preparing the many photomicrographs; J. L. Hascall, who provided the photography; E. H. O'Claire, for performing the nondestructive evaluations, and G. R. Horn, for technical editing. 


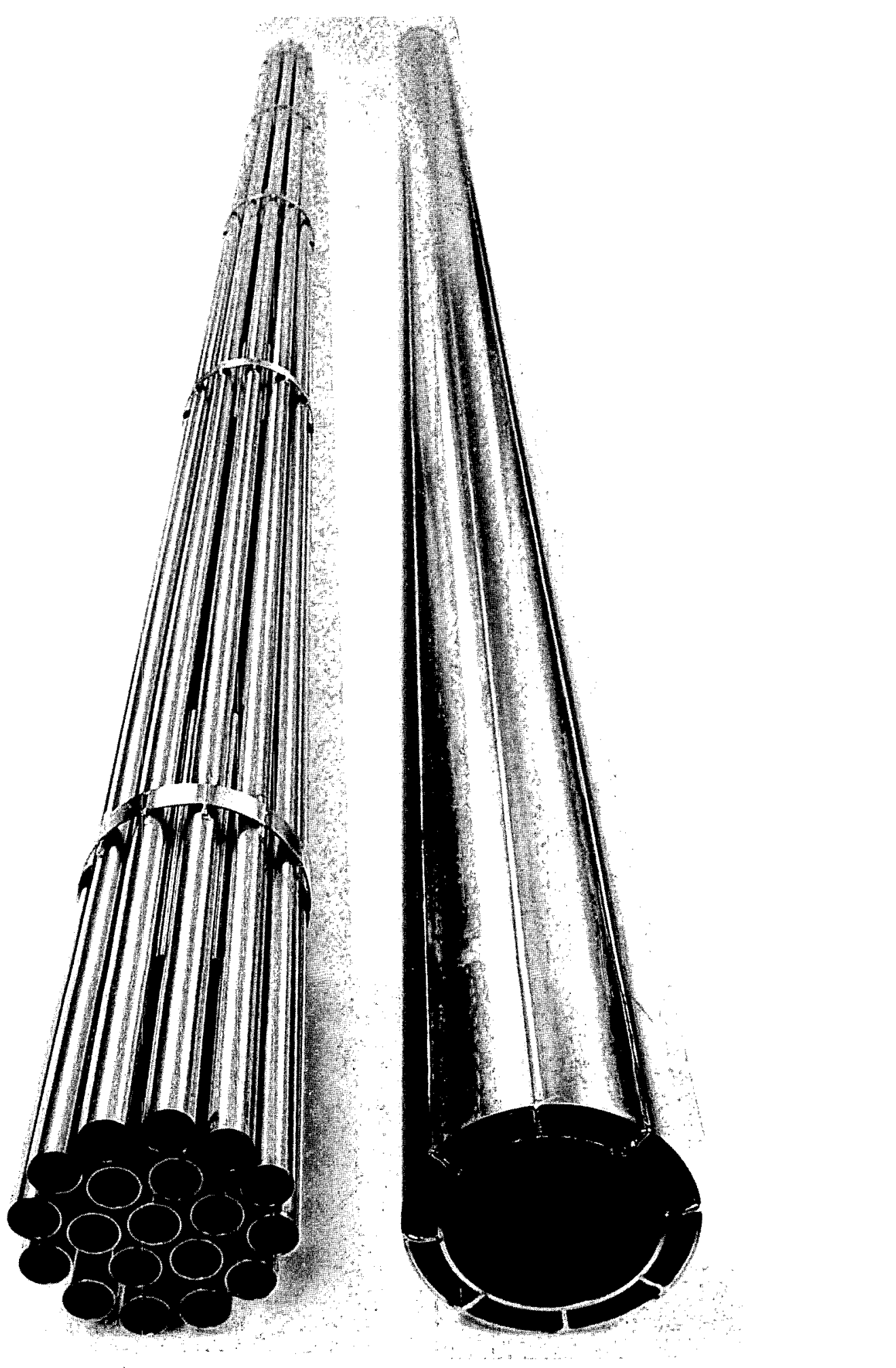

FIGURE 24 Pre-Assembled 19 -Rod Cluster
and Tube-in-Tube Fuel Element Cladding Assemblies 


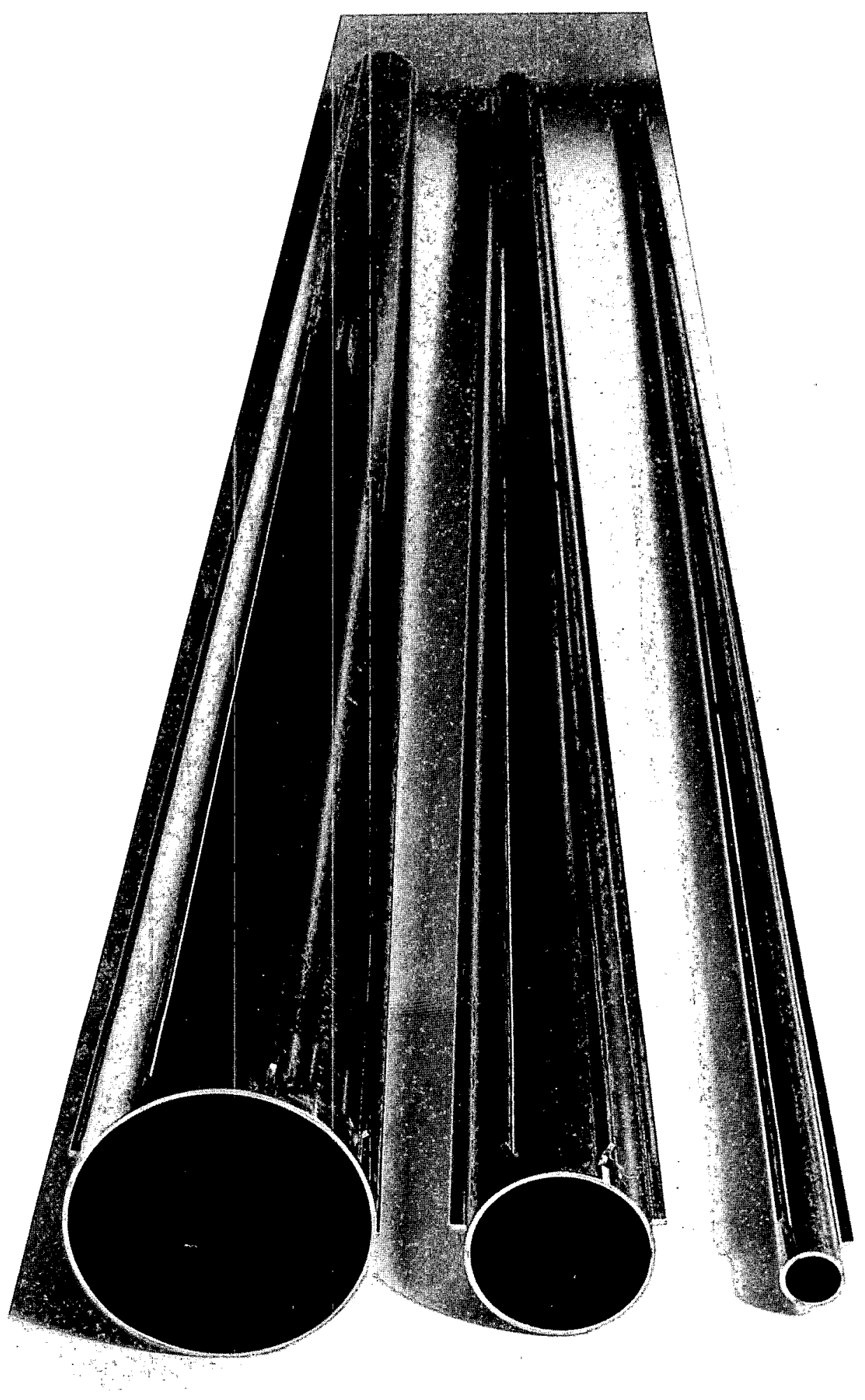

FIGURE 25

Nested Tubular Cladding Parts 


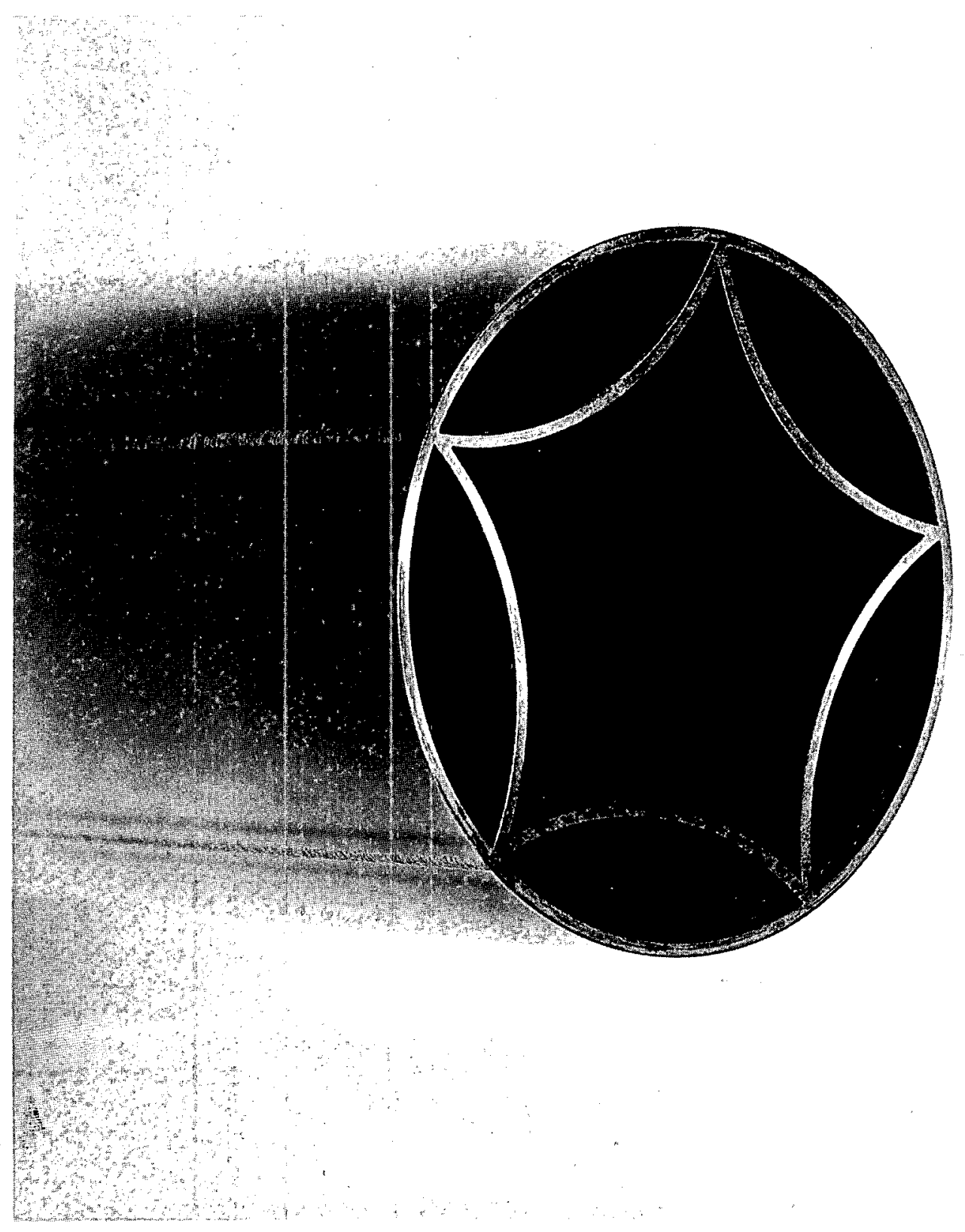

FIGURE 26

Arch-Supported Fuel Element Cladding 


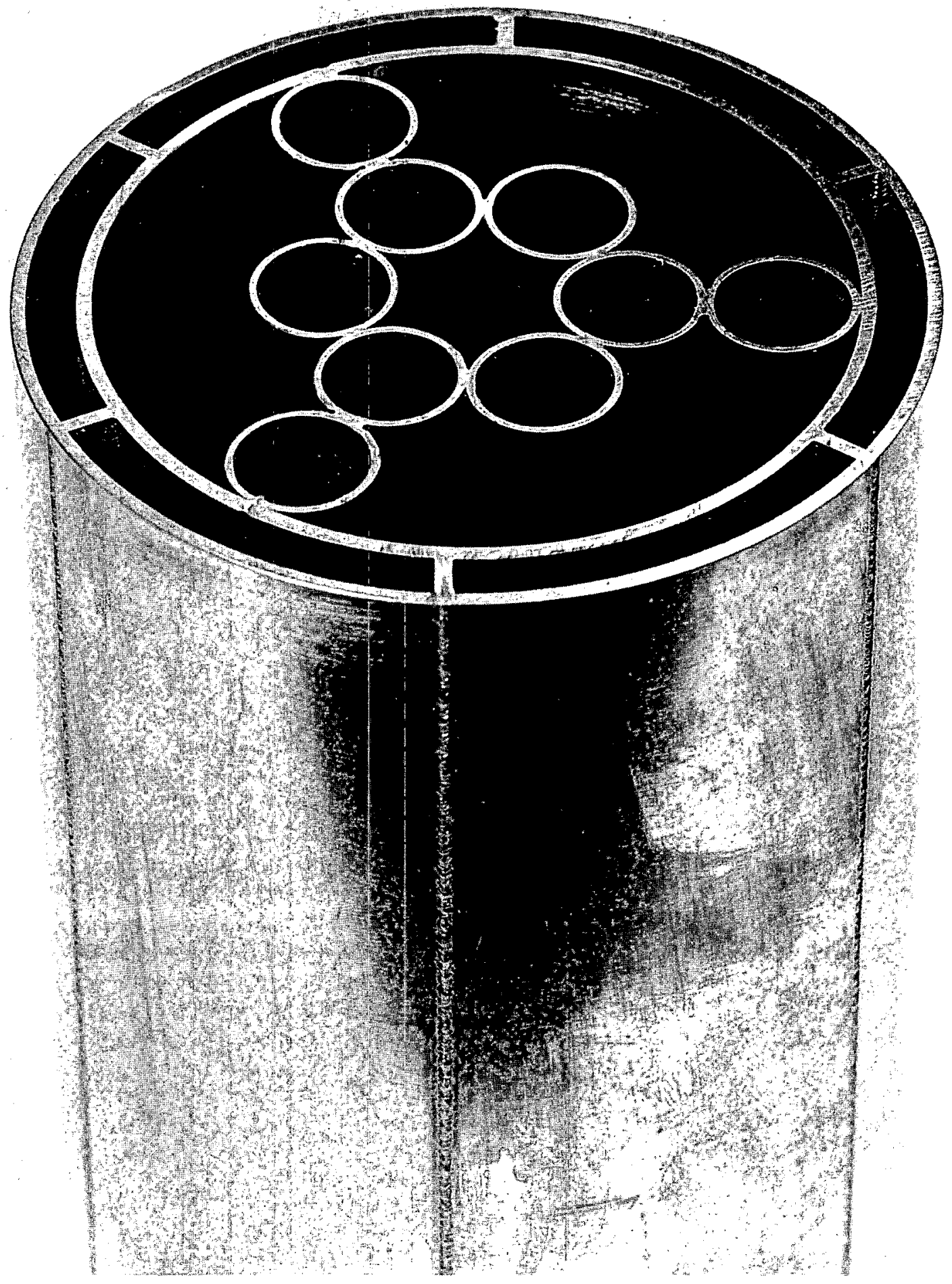

FIGURE 27

Inverted Cluster Fuel Element Cladding 


\section{INTERNAL DISTRIBUTION}

Copy Number

$\begin{array}{ll}1 & \text { F. W. Albaugh } \\ 2 & \text { A. E. Albrethsen } \\ 3 & \text { C. H. Allen } \\ 4 & \text { D. W. Brite } \\ 5 & \text { W. F. Brown } \\ 6 & \text { S. H. Bush } \\ 7 & \text { J. J. Cadwell } \\ 8 & \text { T. B. Correy } \\ 9 & \text { D. R. deHalas } \\ 0 & \text { K. Drumheller } \\ 1 & \text { E. A. Evans } \\ 2-28 & \text { R. F. Klein } \\ 9 & \text { G. A. Last } \\ 0 & \text { E. B. LaVelle } \\ 1 & \text { L. C. Lemon } \\ 2 & \text { L. G. Merker } \\ 3 & \text { L. E. Mills } \\ 4 & \text { J. E. Minor } \\ 5 & \text { R. E. Olson } \\ 6 & \text { W. E. Roake } \\ 7 & \text { R. C. Smith } \\ 8 & \text { W. E. Steinkamp } \\ 9 & \text { K. R. Sump } \\ 0 & \text { J. C. Tobin } \\ 1 & \text { O. J. Wick } \\ 2 & \text { 300 Files } \\ 3 & \text { Record Center } \\ 4 & \text { Technical Publications } \\ 5 & \text { Extra }\end{array}$

\section{EXTERNAL DISTRIBUTION (Special)}

Number of Copies

1

RLOO Technical Information Library

Atomic Energy Commission, Washington

Military Liaison Committee

Attn: Captain D. E. McCoy, Staff Assistant to the Chairman 


\begin{tabular}{|c|c|}
\hline Ptd. & Standard Distribution \\
\hline 3 & ABE RDEEN PROVING GROUND \\
\hline 1 & AEROJET-GENERAL CORPORATION \\
\hline 1 & AEROJET-GENERAL NUCLEONICS \\
\hline 8 & AERONAUTICAL SYSTEMS DIVISION \\
\hline 1 & AEROPROJECTS INCORPORATED \\
\hline & $\begin{array}{l}\text { AABORATORIES } \\
\text { LABOREAR }\end{array}$ \\
\hline 1 & AIR FORCE INSTITUTE OF TECHNOLOGY \\
\hline 1 & ALLIS-CHALMERS MANUFACTURING COMPANY \\
\hline 1 & $\begin{array}{l}\text { ALL IS-CHALMERS MANUFACTURING COMPANY, } \\
\text { SCHENECTADY }\end{array}$ \\
\hline 1 & $\begin{array}{l}\text { ALLIS-CHALMERS MANUFACTURING COMPANY, } \\
\text { WASHINGTON }\end{array}$ \\
\hline 1 & ALLISON DIVISION-GMC \\
\hline 10 & ARG ONNE NATIONAL LABORATORY \\
\hline 1 & $\begin{array}{l}\text { ARMY ENGINEER RESEARCH AND DEVELOP. } \\
\text { MENT LABORATORIES }\end{array}$ \\
\hline 1 & ARMY MISSILE COMMAND \\
\hline 1 & ARMY RESEARCH OFFICE, DURHAM \\
\hline 1 & AEC SCIENTIFIC REPRESENTATIVE, BELGIUM \\
\hline 1 & AEC SCIENTIFIC REPRESENTATIVE, FRANCE \\
\hline 1 & AEC SCIENTIFIC REPRESENTATIVE, JAPAN \\
\hline 3 & ATOMIC ENERGY COMMISSION, WASHINGTON \\
\hline 4 & ATOMIC ENERGY OF CANADA LIMITED \\
\hline 4 & ATOMICS INTERNATIONAL \\
\hline 1 & AVCO CORPORATION \\
\hline 4 & BABCOCK AND WILCOX COMPANY \\
\hline 2 & BATTELLE MEMORIAL INSTITUTE \\
\hline 2 & BEERS (ROLAND F.), INC. \\
\hline 1 & BERYLLIUM CORPORATION \\
\hline 1 & BRIDGEPORT BRASS COMPANY \\
\hline 2 & BROOKHAVEN NATIONAL LABORATORY \\
\hline 1 & BUREAU OF MINES, ALBANY \\
\hline 1 & BUREAU OF SHIPS (CODE 1500) \\
\hline 1 & CARBORUNDUM COMPANY \\
\hline 1 & CHANCE VOUGHT CORPORATION \\
\hline ' & CHICAGO PATENT GROUP \\
\hline
\end{tabular}

\begin{tabular}{|c|c|}
\hline Ptd. & Standard Distribution \\
\hline 1 & CLEVITE CORPORATION \\
\hline 1 & COMBUSTION ENGINEERING, INC. \\
\hline 1 & COMBUSTION ENGINE ERING, INC. (NRD) \\
\hline 1 & DEFENCE RESEARCH MEMBER \\
\hline 1 & DENVER RESEARCH INSTITUTE \\
\hline 1 & DEPARTMENT OF THE ARMY \\
\hline 1 & DOW CHEMICAL COMPANY, ROCKY FLATS \\
\hline 4 & DU PONT COMPANY, AIKEN \\
\hline 1 & DU PONT COMPANY, WILMINGTON \\
\hline 1 & FEDERAL AVIATION AGENCY \\
\hline 1 & FRANKFORD ARSENAL \\
\hline 1 & FRANKLIN INSTITUTE OF PENNSYLVANIA \\
\hline 1 & FUNDAMENTAL METHODS ASSOCIATION \\
\hline 2 & GENERAL ATOMIC DIVISION \\
\hline 1 & GENERAL DYNAMICS/ASTRONAUTICS (NASA) \\
\hline 2 & GENERAL DYNAMICS/FORT WORTH \\
\hline 2 & GENERAL ELECTRIC COMPANY, CINCINNATI \\
\hline 1 & GENERAL ELECTRIC COMPANY, PLEASANTON \\
\hline
\end{tabular}




\begin{tabular}{|c|c|c|c|}
\hline Ptd. & Standard Distribution & Ptd. & Standard Distribution \\
\hline 1 & MARTIN-MARIETTA CORPORATION & 1 & STANFORD UNIVERSITY (SLAC) \\
\hline 1 & MATERIALS RESEARCH CORPORATION & 1 & SYLYANIA ELECTRIC PRODUCTS, INC. \\
\hline 1 & MOUND LABORATORY & 1 & TECHNICAL RESEARCH GROUP \\
\hline 1 & NASA LEWIS RESEARCH CENTER & 1 & TENNESSEE VALLEY AUTHORITY \\
\hline 2 & $\begin{array}{l}\text { NASA SCIENTIFIC AND TECHNICAL } \\
\text { INFORMATION FACILITY }\end{array}$ & 2 & UNION CARBIDE NUCLEAR COMPANY (ORGDP) \\
\hline 2 & NATIONAL BUREAU OF STANDARDS & 5 & UNION CARBIDE NUCLEAR COMPANY (ORNL) \\
\hline 1 & NATIONAL BUREAU OF STANDARDS (LIBRARY) & & $\begin{array}{l}\text { UNION CARBIDE NUCLEAR COMPANY (ORNL- } \\
Y=12)\end{array}$ \\
\hline 2 & NAVAL POSTGRADUATE SCHOOL & 1 & $\begin{array}{l}\text { UNION CARBIDE NUCLEAR COMPANY } \\
\text { (PADUCAH PLANT) }\end{array}$ \\
\hline 3 & NAVAL RESEARCH LABORATORY & 1 & UNITED NUCLEAR CORPORATION (NDA) \\
\hline 1 & NEW BRUNSWICK AREA OFFICE & 1 & U. S. GEOLOGICAL SURVEY, DENYER \\
\hline & NEW YORK OPERATIONS OFFICE & 1 & U. S. GEOLOGICAL SURVEY, MENLO PARK \\
\hline 1 & $\begin{array}{l}\text { NUCLEAR MATERIALS AND EQUIPMENT } \\
\text { CORPORATION }\end{array}$ & 1 & U. S. GEOLOGICAL SURVEY, WASHINGTOK \\
\hline 1 & NUCLEAR METALS, INC. & 2 & UNIVERSITY OF CALIFORNIA, BERKELEY \\
\hline 1 & $\begin{array}{l}\text { OFFICE OF ASSISTANT GENERAL COUNSEL } \\
\text { FOR PATENTS (AEC) }\end{array}$ & 2 & UNIVERSITY OF CALIF ORNIA， LIVERMORE \\
\hline 2 & OFFICE OF NAYAL RESEARCH & 1 & UNIVERSITY OF PUERTO RICO \\
\hline 1 & OFFICE OF NAVAL RESEARCH (CODE 122) & 1 & WATERTOWN ARSENAL \\
\hline 1 & ORDNANCE MATERIALS RESEARCH OF FICE & 1 & WESTERN RESERVE UNIVERSITY (MAJOR) \\
\hline 1 & ORDNANCE TANK-AUTOMOTIVE COMMAND & 4 & $\begin{array}{l}\text { WESTINGHOUSE BETTIS ATOMIC POWER } \\
\text { LABORATORY }\end{array}$ \\
\hline 4 & PHILLIPS PETROLEUM COMPANY (NRTS) & 1 & WESTINGHOUSE ELECTRIC CORPORATION \\
\hline 1 & PICATINMY ARSENAL & 1 & $\begin{array}{l}\text { WESTINGHOUSE ELECTRIC CORPORATION } \\
\text { (NASA) }\end{array}$ \\
\hline 1 & POWER REACTOR DEVELOPMENT COMPANY & & \\
\hline 3 & PRATT AND WHITNEY AIRCRAFT DIVISION & 1 & YANKEE ATOMIC ELECTRIC COMPANY \\
\hline 1 & PURDUE UNIVERSITY & 325 & $\begin{array}{l}\text { DIVISION OF TECHNICAL INFORMATION } \\
\text { EXTENSION }\end{array}$ \\
\hline 1 & RAND CORPORATION & & \\
\hline 1 & RENSSELAER POLYTECHNIC INSTITUTE & & \\
\hline 1 & RESEARCH ANALYSIS CORPORATION & & \\
\hline 1 & SAN FRANCISCO OPERATIONS OFFICE & & \\
\hline 2 & SANDIA CORPORATION, ALBUQUERQUE & & \\
\hline 1 & SANDIA CORPORATION, LIVERMORE & & \\
\hline 1 & $\begin{array}{l}\text { SPACE TECHNOLOGY LABORATORIES, INC. } \\
\text { (NASA) }\end{array}$ & & \\
\hline
\end{tabular}

